\title{
Admitting Mistakes: Home Country Effect on the Reliability of Restatement Reporting
}

\section{Citation}

Srinivasan, Suraj, Aida Sijamic Wahid, and Gwen Yu. "Admitting Mistakes: Home Country Effect on the Reliability of Restatement Reporting." Accounting Review (forthcoming). (This was Harvard Business School Working Paper, No. 13-034, October 2012.)

\section{Published Version}

http://dx.doi.org/10.2308/accr-50887

\section{Permanent link}

http://nrs.harvard.edu/urn-3:HUL.InstRepos:10212561

\section{Terms of Use}

This article was downloaded from Harvard University's DASH repository, and is made available under the terms and conditions applicable to Open Access Policy Articles, as set forth at http:// nrs.harvard.edu/urn-3:HUL.InstRepos:dash.current.terms-of-use\#OAP

\section{Share Your Story}

The Harvard community has made this article openly available.

Please share how this access benefits you. Submit a story.

Accessibility 


\title{
Admitting mistakes: Home country effect on the reliability of restatement reporting
}

\author{
Suraj Srinivasan \\ ssrinivasan@hbs.edu \\ Aida Sijamic Wahid \\ aida.wahid@rotman.utoronto.ca
}

Gwen Yu

gyu@hbs.edu

July 2014

\section{Forthcoming: The Accounting Review}

\begin{abstract}
We study the frequency of restatements by foreign firms listed on US exchanges. We find that the restatement rate of US listed foreign firms is significantly lower than that of comparable US firms and that the difference depends on the firm's home country characteristics. Foreign firms from countries with a weak rule of law are less likely to restate than are firms from strong rule of law countries. While the lower rate of restatements can represent an absence of errors, it can also indicate a lack of detection and disclosure of errors and irregularities. We infer the effect of detection and disclosure by associating the frequency of restatements with the quality of the firm's internal control system. We find that only US firms and foreign firms from strong rule of law countries show a positive association between restatement frequency and internal control weaknesses. Firms from weak rule of law countries show no significant association. We interpret these findings as home country enforcement affecting firms' likelihood of detecting and reporting existing accounting misstatements. This suggests that for US listed foreign firms, less frequent restatements can be a signal of opportunistic reporting rather than a lack of accounting errors and irregularities.
\end{abstract}

Keywords: Accounting restatements, Earnings management, Internal control weakness, Enforcement, SOX 404, accounting quality

Suraj Srinivasan and Gwen Yu are at Harvard Business School; Aida Sijamic Wahid is at the Rotman School of Management, University of Toronto. We are grateful for comments from Mary Barth, John Core, Mihir Desai, Richard Frankel, Paul Healy, OleKristian Hope, Sudarshan Jayaraman, Bin Ke, Volkan Muslu, Krishna Palepu, George Serafeim, Nemit Shroff, Jordan Siegel, Doug Skinner, Stephen Taylor (discussant), Rodrigo Verdi, Shiheng Wang (discussant), Joe Weber, Hal White, Wendy Wilson (discussant), Mort Pincus (the editor), two anonymous reveiwers, and seminar participants at the $23^{\text {rd }}$ Annual Conference for Financial Economics and Accounting, the 2012 Financial Accounting and Reporting Section Midyear Meeting, Chinese University at Hong Kong, the Harvard Business School International Seminar, the 2011 HKUST Accounting Research Symposium, MIT, the 2012 Penn State Accounting Research Conference, the 2011 SMU-SOAR Accounting Symposium, University of Chicago Booth School of Business, and Washington University in St. Louis. We thank D.J. Gannon of Deloitte \& Touche for valuable insights into the audit procedures for US listed foreign companies. We gratefully acknowledge financial support from the Division of Research of Harvard Business School. 


\section{INTRODUCTION}

We examine the reporting of accounting restatements by foreign firms listed in the United States. Accounting rules in the US require firms to issue a restatement correcting prior material errors upon discovery (FASB Accounting Standards Codification 250). ${ }^{1}$ Timely detection and reporting of accounting errors and irregularities ensures that a firm's reported financials are free of any misstatements. Without enforcement that ensures the prudent correction of existing misstatements, there will likely be systematic underreporting of restatements, which will allow "bad" type firms to pool with "good" type firms and possibly lower investors' faith in the reported financials. ${ }^{2}$ Therefore, understanding the determinants of reporting restatements is important to better assess the reliability of reported financials.

The mandatory reporting requirement for restatements implies that the likelihood of an accounting restatement should increase with the existence of accounting errors or irregularities. While more frequent restatements implies more errors or irregularities, it also suggests the presence of internal controls that led to timely detection and disclosure of the misstatement. This is because reporting a restatement involves two steps. First, managers commit an unintentional error or deliberate manipulation that results in misstated accounting numbers. Second, the firm (or its auditor) detects and reports the misstatement (Dyck, Morse, and Zingales 2010; Keune and Johnstone 2012). The second step — the detection and self reporting of the misstatement depends on the firm's and auditor's ability and willingness to comply with reporting rules (Heitzman, Wasley, and Zimmerman 2010). Therefore, observing a restatement is a joint outcome

\footnotetext{
${ }^{1}$ FASB Accounting Standards Codification (ASC) Topic 250 Accounting Changes and Error Corrections states that "Any error in the financial statements of a prior period discovered after the financial statements are issued shall be reported as an error correction, by restating the prior-period financial statements." Also, ASC 105 notes that the provisions of GAAP apply only to material items.

${ }^{2}$ By "good" type we refer to firms that practice high quality financial reporting which is less prone to errors and irregularities. "Bad" type firms are those that are more likely to have errors and irregularities but that are unlikely to detect or disclose the misstatements.
} 
of (i) committing an accounting error or irregularity and (ii) detecting and reporting the misstatement. This two step process implies that a lower rate of restatements indicates fewer accounting mistakes only if there is timely detection and reporting of misstatements.

Many prior studies focus on the first step, showing how restatements are associated with proxies of accounting errors and irregularities (Richardson, Tuna, and Wu. 2002; Doyle Ge, and McVay 2007). In this study, we explicitly consider the second step, which implies that a higher frequency of restatements also suggests better detection and reporting of misstatements.

We use the large number of restatements in recent years by both US and foreign firms listed in the US to examine the reliability of restatement reporting in a cross country setting. ${ }^{3}$ The self reported nature of restatements provides a good setting to assess how home country characteristics influence the financial reporting of foreign firms listed in the US. Further, since foreign firms are subject to the disclosure requirements set forth by the Securities and Exchange Commission (SEC), this setting allows us to examine the effect of home country characteristics on the financial reporting of foreign registrants while generally holding the extent of US regulation constant (Jenkins 1999; Lang, Raedy, and Wilson 2006).

In particular, we examine whether restatement reporting varies by country-level factors that influence how firms comply with the restatement reporting rules. Following prior literature (Ball, Kothari, and Robin 2000), we argue that a company's home country shapes its reporting behavior and that this effect continues even after listing in the US. Lang et al. (2006) document more earnings management in foreign listers compared to US firms, which suggests a higher likelihood of restatements by foreign listers relative to US firms, assuming that misstatements are detected

\footnotetext{
${ }^{3}$ We define reliable restatement reporting as detecting and reporting accounting problems (both intentional and unintentional) in accordance with ASC 250. Reliable restatement reporting ensures that the lack of restatements is indeed indicative of an absence of accounting errors or earnings management.
} 
and reported equally for foreign and US firms. However, if foreign firms fail to report misstatements, due to non-detection or opportunistic reporting, there may be no significant relation between earnings management and the rate of restatements.

Our sample comprises 7,453 firm-year observations for US listed foreign firms from 51 countries between 2000 and 2010. Foreign firms report accounting restatements in $4.7 \%$ of firmyears, compared to $7.3 \%$ for a matched sample of US firms. ${ }^{4}$ We confirm the lower rate of restatements for foreign firms compared to US firms in multivariate tests that control for factors that prior studies have found to be associated with restatements. The coefficient estimate suggests that foreign firms are 46 percent less likely to restate compared to the US matched sample.

Next, we examine whether home-country factors affect the likelihood of restatements. We follow prior papers such as Ball et al. (2000) and Leuz, Nanda, and Wysocki (2003), which document cross-country variation in accounting quality driven by the strength of domestic legal institutions. We use a country-level measure of the rule of law as a summary indicator of the extent of compliance with laws and regulations that can shape a firm's reporting behavior by impacting factors such as auditor effort, investor protection, and managerial self-dealing, among others. Empirically, we use the rule of law index from the World Bank's Worldwide Governance Indicators (Kaufmann, Kraay, and Mastruzzi 2003) used in La Porta, Lopez-de-Silanes, Shleifer, and Vishny (2006). ${ }^{5}$

We find that the frequency of restatements varies with the home country's rule of law. Firms from weak rule of law countries are less likely to restate, with $4.2 \%$ of firms restating, compared

\footnotetext{
${ }^{4}$ The restatements we consider are all made to correct misstatements resulting from a failure to comply with US reporting standards. We do not measure violations of local accounting rules since we are interested in understanding reporting behavior in the US, how it compares to the reporting behavior of similar US firms, and how it varies across countries. Hence we use US reporting requirements as a common basis.

${ }^{5}$ Rule of law measures the extent to which agents have confidence in and abide by the rules of society. These include the effectiveness and predictability of the judicial system, the enforceability of contracts, and perceptions about the incidence of crime in the country (La Porta et al. 2006) as measured in the year 2000.
} 
to $7.5 \%$ for the matched sample of US firms (p-value $<0.001$ ). On the other hand, firms from strong rule of law countries show a smaller difference in their restatement frequency compared to matched US firms $(5.0 \%$ vs. $7.2 \%$ of firm-years, p-value $<0.001)$. The findings hold after distinguishing foreign firms that provide GAAP reconciliation versus those using US GAAP itself. In economic terms, after controlling for other determinants of restatement probability, firms from weak rule of law countries are 42 percent less likely to restate compared to firms from strong rule of law countries.

Fewer restatements from weak rule of law countries can represent an absence of accounting misstatements as well as a lack of detection and disclosure. We distinguish between the two interpretations by relating the frequency of restatements with the quality of the firm's internal control (IC) system measured as the extent of material weaknesses (MW) in its internal controls over financial reporting. Weak internal controls indicate that the firm has a less robust reporting system which increases the possibility of accounting errors, both intentional and unintentional. Thus, if firms correctly report their accounting misstatements, the frequency of restatements will be positively associated with the firm's internal control material weaknesses (ICMW). In contrast, if accounting errors go undetected or unreported, the relationship between restatement frequency and ICMW will weaken. We infer the quality of detection and disclosure by examining the sensitivity of the restatement rate to the effectiveness of the firm's internal control system. ${ }^{6}$

We find that the association between restatement frequency and ICMW increases with the home country's rule of law effectiveness. Firms from weak rule of law countries show no

\footnotetext{
${ }^{6}$ Another predictor of restatements is the level of earnings management (EM) measured using accrual-based models. Such models yield measures of discretionary accruals, that are likely to primarily capture intentional accounting irregularities and not unintentional accounting errors. In additional analysis, we limit our restatement sample to those that are more likely to result from intentional accounting irregularities following Hennes et al. (2008), and use EM as a predictor of such restatements.
} 
evidence of more frequent restatements when there are more ICMW. In contrast, firms from strong rule of law countries and the matched US sample show the expected positive relationship between restatements and ICMW. This suggests that the lower frequency of restatements in weak rule of law countries is due to weaker compliance with restatement reporting, rather than an absence of accounting misstatements. ${ }^{7}$

Foreign firms may restate less if they avoid restating minor errors but report all severe accounting irregularities. We examine this possibility by differentiating restatements involving errors from those with likely accounting irregularities (Palmrose, Richardson, and Scholz 2004; Hennes, Leone, and Miller 2008). We test whether the lower rate is observed for restatements pertaining to accounting irregularities as well as those related to minor errors. We find that foreign firms, especially those from weak rule of law countries, are less likely to report accounting irregularities restatements than comparable US firms. Also, using earnings management $(\mathrm{EM})$ proxies as a predictor of restatements from accounting irregularities, we find that the sensitivity of EM to accounting irregularity restatements is positive and significant only for US firms and foreign firms from strong rule of law countries. For foreign firms from weak rule of law countries, we find no relation between EM and the likelihood of accounting irregularity restatements. This suggests that avoidance of restatement is not limited to errors; it exists even for accounting irregularities.

Our study contributes to a few streams of literature. Articles that examine the causes and consequences of restatements generally focus on US firms and conclude that restatements represent poor earnings quality and that firms suffer capital market consequences as a result

\footnotetext{
${ }^{7}$ We note that ICMW may also be subject to reporting discretion (Gong et al. 2012). More importantly, if factors that affect reporting discretion in ICMW also affect restatement reporting, our findings may be subject to a systematic measurement error. We provide additional test to account for this measurement error (See Section IV).
} 
(Palmrose et al. 2004; Plumlee and Yohn 2010). We highlight two stages in the restatement decision, and show that lower restatement rates may indicate (i) a lower incident of accounting errors or irregularities as well as (ii) the lax detection and disclosure of existing misstatements. The implication of the two step restatement reporting process is that fewer restatements do not necessarily imply higher (or lower) financial reporting quality. Our study highlights that a positive relation between restatements and financial reporting quality depends on the reliable detection and disclosure of misstatements.

Next, our findings have implications for understanding the reporting quality of foreign firms listed in the US. Stringent disclosure rules and the resultant transparency serve as important mechanisms by which foreign firms bond to the US regulatory regime. The lower earnings quality found in Lang et al. (2006) suggests greater errors and irregularities in the financial statements of foreign listers. Despite this, we find that foreign firms are less likely to restate, a finding that has implications for investors and regulators. Prior studies show that investors benefit in a regime that offers effective correction of misstatements since reliable information promotes better resource allocation (Kedia and Philippon 2009; Beatty, Liao, and Yu 2013). ${ }^{8}$ Failure to correct misstatements results in the pooling of good and bad type firms, and such pooling makes it difficult for investors to sort firms based on their economic performance.

Relatedly, the lack of restatements in the presence of errors and irregularities implies fewer ex post penalties, which reduces ex ante discipline in financial reporting. Fewer restatements lowers investors' ability to hold managers and auditors accountable for poor financial reporting

\footnotetext{
${ }^{8}$ Palmrose and Scholz (2004) describe the timely correction of inaccurate disclosures as a mechanism devised under the Securities Acts to ensure that investors possess accurate information for resource allocation decisions. Kedia and Philippon (2009) find that misreporting has real resource allocation effects. They show that low productivity firms hire and invest too much and distort their performance with poor accounting. When misreporting is detected, firms shed labor and capital, improving productivity. Bushman and Smith $(2001,294)$ argue that "managers can identify promising new investment opportunities on the basis of the high profit margins reported by other firms." Beatty et al. (2013) suggest that companies distort their investment behavior based on industry peers' overstated earnings.
} 
through CEO turnover or securities litigation since restatements are a major trigger for both these mechanisms (Johnson, Nelson, and Pritchard 2007; Hennes et al. 2008). ${ }^{9}$ Lawsuits accompanying restatements are less likely to be dismissed and more likely to be settled in favor of the plaintiff (Johnson et al. 2007) and for larger amounts (Brochet and Srinivasan 2013) than lawsuits without restatements. Cheng, Srinivasan, and Yu (2013) show that foreign listers are less likely to be sued in securities lawsuits compared to US firms, in part due to fewer restatement triggers. Firms that do not correct misstatements face lower risk of SEC action since restatements prompt SEC investigations and investor scrutiny (Karpoff et al., 2008; Files, Swanson, and Tse 2009). Therefore, our results imply that US listed foreign firms may be underscrutinized by US public and private enforcement mechanisms. Our findings suggest that companies from countries with weaker domestic RoL are a potential focus area for investors and regulators (e.g., SEC, PCAOB) to better identify firms with opportunistic restatement behavior.

The remainder of the paper is organized as follows. Section II reviews the literature and develops our hypotheses. Section III describes the data and empirical tests; Section IV presents our results. In Section V, we present additional analyses and conclude in Section VI.

\section{HYPOTHESIS DEVELOPMENT AND INSTITUTIONAL DETAILS}

\section{Home Country Effect and Reporting by Foreign Firms Listed in the US}

Foreign firms listed in the US follow financial reporting requirements set forth by the SEC and relevant laws such as the Securities Exchange Act of 1934 and the Sarbanes-Oxley Act of 2002 (SOX). These companies are required to make ongoing filings with the SEC and are subject

\footnotetext{
${ }^{9}$ Restatements are often followed by disciplinary managerial and board turnover (Desai, Hogan, and Wilkins 2006; Srinivasan 2005) and auditor turnover (Hennes et al. 2013). Companies also make governance and disclosure improvements to regain reputation (Chakravarthy, DeHaan, and Rajgopal 2013).
} 
to SEC oversight. Prior research considers this commitment to ongoing disclosure and the enforcement of securities laws to be among the benefits of listing in the US (Karolyi 2006). In addition to subjecting firms to generally higher quality reporting standards, US listing can increase reporting quality by stricter monitoring of auditors. Auditors of firms listed in the US face higher litigation risk than those in other countries (La Porta et al. 2006; Choi et al. 2009), and monitoring by the Public Company Accounting Oversight Board (PCAOB), which can lead to a superior audit effort. ${ }^{10}$ Case law shows that provisions of the securities laws extend to all auditors of US registrants, even if the auditors are not US based (Seetharaman, Gul, and Lynn 2002).

Despite such monitoring, prior studies find that the quality of disclosure by US listed foreign firms is not on par with that of US firms. Lang et al. (2006) find that earnings of foreign issuers show more evidence of earnings management than earnings of US firms. They also find that the accounting quality of cross-listed firms varies systematically by home country characteristics such as investor protection and legal enforcement. Foreign firms from weak investor protection countries are less likely to voluntarily report incidents of internal control weaknesses (Gong, Ke, and Yu 2012) and to provide management forecasts (Hope, Kang, and Kim 2012). These findings suggest that US regulation, monitoring by the SEC, and the demands of US investors do not completely harmonize the disclosure quality of US listed foreign firms with that of US firms.

There are reasons to expect the restatement rate of US listed foreign firms to differ from that of US firms. Restatements correct both unintentional errors and intentional accounting irregularities. Plumlee and Yohn (2010) finds that the majority of the restatements in the US arise

\footnotetext{
${ }^{10}$ For example, for foreign registrants, the quality control standards of PCAOB (SECPS 1000.08) in Appendix K require a qualified auditor familiar with SEC rules and regulations ("filing reviewer") to review the sample audit procedure of all non-US auditors.
} 
from unintentional errors. To the extent that US listed foreign firms incur more errors from misapplying GAAP, they can have more restatements. Also, Lang et al. (2006) show that foreign firms listed in the US show more earnings management compared to similar US companies. If earnings management proxies capture the level of accounting irregularities, one would expect financial statements of foreign firms to show a higher rate of restatements.

The prediction that more accounting errors and irregularities will lead to higher restatement rates assumes that most errors and irregularities are detected and reported. However, firms can have incentives to avoid correcting misstatements because truthful reporting of misstatements, whether intentional or unintentional ones, will draw investors' attention and undermine the credibility of financial statements (Palmrose and Scholz 2004; Collins, Masli, Reitenga, and Sanchez 2009; DeHaan, Hodge, and Shevlin 2012). US listed foreign firms can be sensitive to such incentives, as one reason for listing in the US is to signal high quality by bonding to a stricter financial reporting regime (Coffee 2002). If such foreign firms are less likely to detect and report existing errors and irregularities, it is possible that the restatements rates may be lower for US listed foreign firms compared to US firms.

Prior research suggests that the extent of bonding to the US regulatory and governance regime differs systematically across countries (Frost and Pownall 1994). There are differences across countries in the domestic supply of expert intermediaries such as auditors, analysts, lawyers, and institutional investors, and in the extent of enforcement by local capital market regulators. In fact, enforcement by the SEC and private litigation also relies on local infrastructure (e.g., lawyers and auditors) to support enquiries and action in the home country. Consistent with this, Leuz et al. (2003) find that foreign firms exhibit more evidence of earnings management, 
especially in countries with weak enforcement. ${ }^{11}$ If US listed foreign firms continue to engage in more earnings management and even more so when they are from weak rule of law countries, the likelihood of restatements for firms from these countries will be higher. However, if US listed foreign firms are less likely to detect and report existing misstatements, these firms may exhibit a lower rate of restatements relative to US firms, despite higher earnings management levels. We initially examine whether the restatement rate of US listed foreign firms differs from that of US firms and then test $\mathrm{H} 1$ as to whether the difference varies by home country characteristics.

H1: The probability of restatements by foreign firms cross-listed in the US will vary by the level of home country rule of law.

We use the measure "rule of law (RoL)" in the home country from La Porta et al. (2006) as a summary measure to capture the variation across countries on all of the dimensions discussed above. We believe this parsimony to be desirable and necessary, as many of the local institutional development measures are highly endogenous. This measure has been widely used in the prior literature (e.g., Doidge, Karolyi, and Stulz 2007). We also confirm the robustness of the results with the alternate measure of the RoL index used in Leuz et al. (2003). ${ }^{12}$

Simply comparing the frequency of restatements may indicate (i) a higher occurrence of accounting problems as well as (ii) the prudent detection and disclosure of existing errors. Because the purpose of our study is to highlight the second step - the detection and disclosure of errors - we examine the sensitivity of restatement rates to the effectiveness of a firm's ICs, a firm

\footnotetext{
${ }^{11}$ While prior studies suggest that there are significant differences in reporting behavior across countries, countrylevel factors need not play any role in the reporting quality of US listed foreign companies if high quality firms are able to overcome weak country-level institutions when they cross-list. Alternately, lower quality firms can continue to show opportunism even when they are from a strong rule of law country.

${ }^{12}$ Following Leuz et al. (2003), the alternative measure of the strength of a country's law enforcement institutions is the mean score of three law enforcement variables identified in La Porta et al. (1998). The three measures are the original rule of law measure and two additional proxies based on assessments from risk rating agencies that attempt to capture (i) the efficiency and integrity of the country's judicial system and (ii) the degree of government corruption. Our results remain unchanged when using this alternative measure of enforcement.
} 
characteristic that is negatively related to the extent of the accounting problems. That is, in addition to comparing the levels of restatement frequency, we examine the sensitivity of restatements to the presence of ICMW to infer the detection and reporting of existing errors.

We infer the level of discretion in restatement reporting using the association between restatements and ICMW. Prior studies demonstrate a link between the quality of the firm's internal controls over financial reporting and the likelihood of subsequent accounting restatements (Hammersley, Myers, Shakespeare 2008; Plumlee and Yohn 2010). Firms with weak internal control systems show a higher likelihood of accounting misstatements (DeFond and Jiambalvo 1991). Thus, if firms correctly acknowledge their accounting errors and irregularities (i.e., misstatements), the frequency of restatements will be positively associated with ICMWs. In contrast, if restatements are concealed, we expect to find a less significant relationship between restatement frequency and ICMWs. If US listed foreign firms' likelihood of detecting and reporting existing accounting problems varies by the home country RoL, we expect the link between ICMWs and restatement likelihood to differ by the RoL.

H2a: The relation between the probability of restatement (both errors and irregularities) and ICMW will be weaker when the US listed firm is from a country with weak RoL.

Following Hennes et al. (2008), we also distinguish between restatements that involve unintentional errors and those that likely effect intentional accounting irregularities. One possible explanation for less frequent restatements in weak RoL countries may be that in these firms, only restatements related to intentional accounting irregularities are reported. Mistakes that go unreported may be limited to minor errors. Thus we test the above hypothesis after limiting our sample to restatements due to accounting irregularities.

As an alternative to using ICMW, which predict the probability of errors as well as accounting irregularities, we use the level of earnings management (EM) as a predictor of 
accounting irregularity restatements. Our null hypothesis is that there is no difference in the link between EM and accounting irregularity restatements among US listed foreign firms. If the extent of compliance in detecting and reporting such restatements differs by home country RoL, we predict the relationship between EM and restatements to increase with home country RoL.

$H 2 b$ : The relation between the probability of a restatement related to accounting irregularities and earnings management will be weaker for a US listed firm from a country with weak RoL.

\section{SAMPLE AND DESCRIPTIVE STATISTICS}

\section{Sample Construction}

Our sample consists of all foreign firms listed on major US exchanges — NYSE, NASDAQ, and AMEX — from 2000 to 2010. We include both American Depository Receipts and firms directly listed on US exchanges. We exclude OTC firms because such firms are not required to register with the SEC and therefore do not need to follow US disclosure practices (Doidge 2004).

We classify firms as foreign if they are headquartered outside the US, regardless of the place of incorporation, using the variable LOC from Compustat. ${ }^{13}$ We drop firm-years that lack the financial data in Compustat and CRSP needed to compute the variables in our regression models. The selection criteria provide us with a sample of 1,357 unique foreign firms and 7,453 firmyears. The restatement sample is obtained from Audit Analytics. We define the restatement observations to reflect a single announcement rather than all the restated years. If a restatement spans multiple years, we include the most recent year of the restating period. ${ }^{14}$

\footnotetext{
${ }^{13}$ US incorporated firms with foreign headquarters are often foreign firms that acquired a US domiciled firm (a reverse merger) to get listed in the US. We include reverse-merger firms in our foreign firm sample, since such firms are better characterized as non-US firms.

${ }^{14}$ Including only one observation for each restatement alleviates the concern that our sample may be confounded by the time it takes for a firm to correct the error (i.e., the restatement duration). We use the last year because it is closest to when the errors are detected. Our results, however, are robust to the inclusion of all the years of the restatement.
} 
We partition the foreign firm sample by RoL in the home country, using the RoL index from the World Bank's Worldwide Governance Indicators following La Porta et al. (2006). ${ }^{15} \mathrm{We}$ classify firms as strong and weak RoL country-firms using our sample country median $(=1.64)$ of the RoL index. We create a matched sample of US firms to compare restatement rates of foreign and US firms. The matched sample is obtained by performing an exact match on year and industry and a propensity score match based on four firm characteristics - size, leverage, ROA, and book-to-market - for each firm-year. Table 1 presents the distribution of firm-year observations and restatements for all countries from 2000 to 2010. Foreign firms, on average, restate less than do US firms. Panel A shows that of the 2,950 firm-years in the weak RoL group, 123 (4.2\%) were restated, while Panel B shows that of the 4,503 firm-years in the strong RoL group, $224(5.0 \%)$ were later restated. For both the weak and strong US matched samples, the restatement rates are significantly higher (7.5\% and $7.2 \%$, respectively).

Table 1 also presents the frequency of different types of restatements - those due to accounting irregularities and those related to core accounts. Following prior literature, we identify restatements related to accounting irregularities via (i) ex post measures using external (e.g., the SEC or DOJ) or internal (board of directors) investigations (Hennes et al. 2008) and (ii) ex ante measures using the core/non-core account classification (Palmrose et al. 2004). In Panel B, column (6), we show that foreign firms (from both weak and strong RoL countries) are less likely to report restatements due to accounting irregularities (1.2\%) relative to their matched US sample $(4.1 \%)$. Given that prior literature suggests that earnings management behavior is more prevalent among foreign cross-listed firms than it is among US firms (Lang et al. 2006), the

\footnotetext{
${ }^{15}$ The RoL variable is measured in year 2000. We follow much cross-country research (such as Leuz et al., 2003) that considers such fundamental characteristics as being stable over time. In Section V, we also use the adoption of IFRS as a positive shock to a country's reporting regime to examine a time-varying effect unlike RoL which is static.
} 
finding that foreign firms report fewer restatements related to accounting irregularities is unexpected if taking detection and disclosure for granted.

Table 2, Panel A presents the descriptive statistics for the firm and governance characteristics of the foreign and matched US sample. All variables are defined in the appendix. Firms from weak RoL countries are similar in size and leverage, have higher profitability (ROA), and fewer growth opportunities (i.e., higher book-to-market ratio) compared to firms from the US matched sample. Firms from weak RoL countries are audited by a Big Five (or Four) audit firm less frequently $(66.7 \%)$ relative to firms from strong RoL countries $(69.0 \%)$ and the US sample (79.4\%); they have smaller ownership by US institutions (18.1\% vs. $20.1 \%$ and $60.5 \%)$, less analyst coverage (4.07 vs. 6.40 and 9.17), and are less likely to prepare financials using US GAAP rather than local GAAP with reconciliation to US GAAP (64.7\% vs. 81.3\% and 99.5\%).

\section{Predictors of Accounting Restatements}

To infer the magnitude of detection and disclosure of misstatements, we examine the sensitivity of restatements to the predictors of accounting restatements, i.e., ICMWs and earnings

management (EM). We use $I C M W$ as a predictor of all restatements and $E M$ as a predictor of only those restatements that involve accounting irregularities. Greater sensitivity suggests more prudent detection of existing accounting errors and irregularities.

\section{Internal Control Material Weakness}

ICMW are based on Section 404 disclosures obtained from Audit Analytics. Prior literature shows that good internal control systems increase the reliability of financial reporting (Doyle et al. 2007; Ashbaugh-Skaife, Collins, Kinney, and Lafond 2008). For US accelerated filers, an auditor's assessment of internal controls became mandatory under Section 404 of SOX starting in November 2004. For US listed foreign firms, such an assessment was required only from 
fiscal years ending on or after July 2006. To ensure that our measure of ICMWs is not affected by firms that voluntarily adopted the requirement earlier, we limit our analyses involving ICMW to those reported under Section 404 from 2007 to 2010 when an auditor's assessment of internal controls was mandatory.

We use the original ICMW reports, not the amended reports, to avoid counting ICMWs that were revealed due to the restatement itself. When firms restate their financials, if their auditor had not previously reported an ICMW for the misstatement year, which is commonly the case (Rice and Weber 2012), then the auditor issues an amended ICMW report to inform investors that internal controls were not effective in the fiscal year the misstatement occurred. Because restatement announcements often result in subsequent ICMW disclosures, using the amended report would result in the identification of a mechanical relation between restatements and ICMWs, i.e., ICMW caused by restatements, rather than the identification of ICMW disclosure as predictors of restatements. Therefore, we include only the ICMWs from the original version of the ICMW effectiveness report and exclude any ICMW from the amended filing, which includes ICMW revealed by the restatement event. Using the original ICMW report allows us to focus exclusively on ICMWs that precede the restatement announcement.

Panel A of Table 2 shows the frequency of ICMWs in our sample. Over the 2007-2010 period, $7.9 \%$ of firm-years have ICMWs for firms from weak RoL countries, compared with $3.4 \%$ for the US matched sample and $5.1 \%$ for firms from strong RoL countries. While the univariate evidence in Table 2 make it appear as if the extent of ICMW are higher in weak RoL countries $(7.9 \%)$ as opposed to strong RoL countries $(5.1 \%)$, we note that this effect is not evident in multivariate comparison once we control for various firm characteristics. In 
untabulated analysis, we find no significant difference between weak RoL and strong RoL in their frequencies of ICMW disclosures under Section 404.

\section{Earnings Management}

We use four earnings management measures from prior literature: i) the proportion of small positive income (EM1; Burgstahler and Dichev 1997), ii) the magnitude of total accruals measured as the ratio of the absolute value of total accruals to the absolute value of operating cash flows (EM2; Leuz et al. 2003), iii) accruals quality (EM3: Dechow and Dichev 2002), and iv) the level of discretionary smoothing (EM4; Francis, LaFond, Olsson, and Schipper 2005). They are all estimated at the firm-year level using "as reported" financials, i.e., un-restated numbers. We sign the measures so that higher values reflect more earnings management. Detailed definitions are in the appendix.

The underlying accounting standards used for the financials reported in Compustat vary by the firm's reporting choice. US listed foreign firms can use US GAAP, IFRS (as promulgated by the IASB), or local GAAP with reconciliation to US GAAP. We collect the foreign firms' accounting standards from Capital IQ. One concern with using reported financials is that the differences in accounting standards can affect the EM proxies. This can bias our inferences, particularly if the firm's reporting choice varies systematically by its home country RoL. Therefore, in addition to controlling for the accounting standard (Reporting standards) in our tests, we examine the sensitivity of our results to dropping observations that report using local GAAP with reconciliation. Untabulated analysis shows that our inferences remain unchanged.

Table 2, Panel B presents the descriptive statistics of the EM measures. Firms from strong RoL countries have a higher level of earnings management relative to the matched US firms on three of the four EM measures. Similarly, firms from weak RoL countries have a higher level of 
earnings management relative to the matched US firms with the exception of the EM1 measure. The EM1 measure, which is the \% of firm-years with a small positive income, is higher for the matched US sample than for both the weak and strong RoL samples. For our empirical analysis, we use an aggregate EM Index using all four measures for each firm-year.

We construct the EM index by first ranking each measure and then using the average percentile rank of all four EM proxies. Since firm-level EM measures have measurement errors (Dechow, Ge, and Schrand 2010), we use the quintile rank of the aggregate EM index in our empirical analysis. ${ }^{16}$ Table 2, Panel B shows that firms from weak RoL countries have a significantly higher level of earnings management than the matched US sample based on the overall EM index (p-value<0.001). However, the difference in the EM index between firms from strong RoL countries and their matched US sample is not statistically significant ( $\mathrm{p}$-value $=0.41$ ).

\section{Restatement Characteristics}

Table 3 presents descriptive statistics relating to restatement characteristics over the 20002010 period. Out of the 347 restatements by foreign firms, 123 (224) are by firms from weak RoL (strong RoL) countries. US listed foreign firms are less likely than the matched US firms to use visible disclosure methods such as $8-\mathrm{K}$ or $6-\mathrm{K}$ reports. Also, the time to discovery, which is the number of months from the end of the misstatement period to the restatement announcement date, is four months longer for firms from weak RoL countries compared to US matched firms. This can reflect the lack of quarterly reporting for some foreign firms. In terms of the accounts

\footnotetext{
${ }^{16}$ Leuz et al. (2003) argue that firm-level accounting quality metrics are less noisy when aggregated at the country level. In untabulated analysis, we compute a country-level EM measure using the country median of our sample firms. For each country-year, we rank each EM measure into percentile ranks and use the average of all four EM measures as the country-level EM index. We then examine the correlation of the country-level EM index and restatement probability and find a significant positive correlation (coeff $=0.396$, $\mathrm{p}$-value $<0.01$ ). The positive correlation motivates our later test using EM measures as a predictor of restatements.
} 
restated, foreign firms from weak RoL countries are less likely to report restatements related to core items as described in the appendix (Palmrose et al. 2004) relative to the matched US firms.

In terms of consequences, univariate evidence in Table 3 suggests that a firm is likely to face similar regulatory or legal actions regardless of its country of origin once it reports a restatement. Securities litigation are triggered by $19.6 \%$ (16.3\%) of restatements by firms from weak RoL countries (the matched US sample). The SEC investigates $8.9 \%$ (6.1\%) of firms from weak RoL countries (the matched US sample). Both these differences are not statistically significant. As a comparison, $14.2 \%$ and $8.5 \%$ of restatements by firms from strong RoL countries lead to securities litigation and an SEC investigation respectively, figures that are lower but not statistically different from those observed in the matched sample of US firms.

We observe significant differences in CEO turnover following restatements: CEO turnover rates for firms from both weak and strong RoL countries ( $4.1 \%$ and $5.4 \%$ respectively) are significantly lower than in the matched samples of US firms ( $11.8 \%$ and $11.1 \%$ respectively). This indicates that CEO turnover, which is another method for identifying restatements related to severe accounting irregularities for US firms (Badertscher, Phillips, Pincus, and Rego 2009), may have limited power in an international context. For this reason, we rely on other measures, using (i) external or internal investigations and (ii) the core/non-core account classification.

\section{EMPIRICAL RESULTS}

\section{Frequency of Restatements and the Home Country Effect}

We first examine how the likelihood of restating differs for US listed foreign firms and matched US firms. Since we use ICMW as the predictor, the sample period for this analysis starts from 2007 when auditor's assessment of ICMW became mandatory for US listed foreign firms, 
and hence the sample size is smaller than in Table 1 (the sample size for this analysis is provided in the description of the $I C M W$ variable in Table 2 Panel A). We use the following logit model:

Restatement $_{\mathrm{i}, \mathrm{t}}=\beta_{0}+\beta_{1} \times$ Foreign firm indicator $_{\mathrm{i}}+\beta_{2} \times \mathrm{ICMW}_{\mathrm{i}, \mathrm{t} \text {, before }}+\beta_{3} \times \mathrm{EM}$ Index $_{\mathrm{i}, \mathrm{t}, \text { before }}$ $+\beta_{4-14} \times$ Controls $_{\mathrm{i},-1-1}+$ Industry FE + Year FE $+\varepsilon_{\mathrm{i}, \mathrm{t} \cdot}(1)$

The dependent variable Restatement $t_{\mathrm{i}, \mathrm{t}}$ equals 1 if firm $i$ restated financial statements for year $t$, and zero otherwise. For restatements that affect multiple firm-years, we include only the most recent year of the restatement as described earlier. Foreign firm indicator is the primary variable of interest and equals 1 for firms from a non-US country, zero otherwise.

We control for the likelihood of accounting errors and irregularities using a measure of the quality of internal control systems (ICMW) and the earnings management measure (EM Index). $I C M W_{i, t, b e f o r e}$ is an indicator variable equal to 1 if the firm reported an ICMW for year $\mathrm{t}$, prior to identifying the need to restate the financials, and zero otherwise. The subscript before denotes that the measure represents values before identifying the need to restate the year $t$ 's financials. As discussed earlier, we use the original ICMW effectiveness report to focus exclusively on ICMWs which precede the discovery of year $t$ 's restatement. EM Index $x_{i, t, b e f o r e}$ is the earnings management index variable constructed using the unrestated financials. For restatements that affect multiple firm-years, we use the EM measure for the most recent year of the restatement. We also use a number of control variables hypothesized to affect the likelihood of a restatement. Firm characteristics include size, leverage, profitability, and growth (DeFond and Jiambalvo 1991; Badertscher et al. 2009). We also include complexity, measured as the number of business segments, and measures of the firm's monitoring environment: auditor, analyst following, and institutional ownership. Following Lang et al. (2006), we control for whether the foreign firm reports using US GAAP (or IFRS) or using local GAAP with reconciliation to US GAAP. 
Finally, we include year and industry fixed effects to control for unobservable time and industry factors that may affect the restatement probability. Standard errors are clustered by firm.

Next, we repeat our analysis within the foreign sample and examine whether the probability of restatements varies by home country RoL (Hypothesis 1) using the following logit model. Restatement $_{\mathrm{i}, \mathrm{t}}=\beta_{0}+\beta_{1} \times$ Weak RoL indicator $_{\mathrm{i}}+\beta_{2} \times \mathrm{ICMW}_{\mathrm{i}, \mathrm{t} \text { before }}+\beta_{4-14} \times$ Firm Controls $_{\mathrm{i}, \mathrm{t}-1}$ $+\beta_{15-17} \times$ Country Controls $\mathrm{s}, \mathrm{t}-1_{1}+$ Industry FE + Year FE $+\varepsilon_{\mathrm{i}, \mathrm{t}} .(2)$

Weak RoL indicator is an indicator variable that equals 1 for firms from weak RoL countries, and zero otherwise. Additionally, to mitigate the possibility that the weak RoL partition is capturing other control characteristics, we include country-level controls such as differences in local accounting versus US GAAP (Accounting differences), capital market development (Country market cap), economic growth (Country GDP growth), or differences in auditor legal liability (Auditor liability), all of which may be associated with the propensity to restate.

Table 4 presents the results from estimating the models in equations (1) and (2). First, we include all sample restatements (columns (1) and (2)) and then only restatements related to accounting irregularities (columns (3) and (4)). Column (1) presents results from equation (1) using the foreign and matched US samples. The coefficient on Foreign firm indicator is negative and statistically significant (coef. $=-0.637$, p-value $=0.007$ ), suggesting that US-listed foreign firms are less likely to restate their financials relative to matched US firms. The estimated coefficient suggests that the probability of foreign firms restating is $1.9 \%$ when evaluated at the mean of the control variables. The comparable probability of the US matched sample is $3.5 \%,{ }^{17}$

\footnotetext{
${ }^{17}$ To compute the predicted probabilities, we evaluate each coefficient at the sample mean and calculate the predicted probability as $1 /(1+$ exponent of the negative summed value). For example, for the matched U.S. sample, the summed value of each coefficient at the sample mean is -3.30 . The resulting calculation of the predicted probability is $1 /(1+\exp (3.30))=3.5 \%$. Similarly, the calculation for the foreign firm sample is $1 /(1+\exp (3.95))=1.9 \%$.
} 
suggesting that foreign firms are $46 \%$ less likely to restate their financials than the US matched firms, after controlling for other determinants of restatements.

Column (2) shows the estimated coefficients of equation (2) using only the foreign firm sample. The coefficient on the Weak RoL indicator is negative and statistically significant (coef.=-0.795, p-value=0.071), indicating that firms from weak RoL countries are less likely to restate their financials compared to firms from strong RoL countries. In economic terms, this implies that firms from weak RoL countries are $42 \%$ less likely to restate their financials than firms from strong RoL countries are, after controlling for other determinants of restatements. ${ }^{18}$

In column (3), we examine the effect of the Foreign firm indicator on irregularities restatements. Following Hennes et al. (2008), we define irregularities restatements as restatements that involve an external or internal investigation. ${ }^{19}$ The coefficient on Foreign firm indicator is negative and statistically significant (coef. $=-1.026, \mathrm{p}$-value $=0.005)$ and the economic magnitude is greater than the earlier analysis using all restatements. Column (4) estimates the Weak RoL effect using only the foreign firm sample. We find that the Weak RoL indicator is negative and statistically significant (coef.=-1.646, p-value=0.018), with greater economic magnitude compared to column (2). Overall, the results imply that foreign firms, especially those from weak RoL countries, are less likely to restate than comparable US firms. The lower restatement rate of foreign (weak RoL) firms becomes even more pronounced for restatements related to accounting irregularities. We observe a statistically insignificant coefficient on the EM Index in columns 2, 3, and 4. As we will see later (in Tables 4 and 5), earnings management is a

\footnotetext{
${ }^{18}$ The estimates suggest that the probability of firms from weak RoL countries restating is $1.10 \%$ when evaluated at the mean of the control variables. For foreign firms from strong RoL countries, the comparable probability is $1.88 \%$.

${ }^{19}$ Audit Analytics identifies restatements that are accompanied by a board of directors investigation. These do not include investigations initiated by managers as in Hennes et al. (2008).
} 
good predictor of restatements only in the US and strong RoL countries. The coefficient loses its significance in the combined samples likely due to the inclusion of the weak RoL sample.

\section{Home Country Effect and Restatements Conditional on the Level of ICMW}

The evidence discussed in the previous section suggests that foreign firms, especially from weaker RoL countries, report fewer restatements. There are two ways one can interpret the lower restatement rates. First, firms from weak RoL countries can have fewer accounting errors and irregularities and therefore less need to restate their financials. The other interpretation is that errors and irregularities are more likely to go undisclosed in firms from weak RoL countries. So far, we controlled for the level of existing errors and irregularities using proxies of ICMW and EM and drew inferences consistent with the second interpretation. In other words, we inferred less detection and reporting from the lower restatement rates by conditioning on ICMW and EM.

ICMW and earnings management are our proxies for the underlying extent of weaknesses in the accounting system. We conjecture that the lower rate of restatements seen in Table 4 is because in US companies underlying weaknesses are more likely to result in a restatement than in foreign companies. Similarly, in countries with better enforcement, underlying weaknesses are more likely to result in restatements than in countries with weaker enforcement. Therefore, we examine if ICMW are more strongly related to restatements of US firms compared to foreign

firms. We repeat this comparison for companies in weak and strong RoL countries. Empirically, we test for differences in the extent of the detection and disclosure of existing irregularities using the sensitivity of the restatement rates to the level of ICMW, i.e., we compare the coefficient on ICMW across the foreign versus US samples (and weak versus strong RoL samples).

We use the logit model in equation (3) and compare the difference in the coefficients on the ICMW variable for the foreign and US matched sample using a seemingly unrelated 
regression (SUR) model. The advantage of separately estimating the coefficients across the different samples is that it allows all predictors, including $I C M W$, to vary across the two samples. The specification is equivalent to interacting all the control variables with the foreign (or RoL) indicator variable to capture the differences in the prediction model for the two samples.

$$
\begin{array}{r}
\text { Restatement }_{\mathrm{i}, \mathrm{t}}=\beta_{0}+\beta_{1} \times \mathrm{ICMW}_{\mathrm{i}, \mathrm{t} \text {,before }}+\beta_{2} \times \mathrm{EM} \mathrm{Index}_{\mathrm{i}, \mathrm{t}, \mathrm{before}}+\beta_{3-14} \text { Firm Controls }_{\mathrm{i}, \mathrm{t}-1} \\
+\beta_{15-17} \text { Country Controls } \mathrm{c}_{\mathrm{c}, \mathrm{t}-1}+\text { Industry FE }+ \text { Year FE }+\varepsilon_{\mathrm{i}, \mathrm{t} \cdot}
\end{array}
$$

We compare the sensitivity of restatements to $I C M W_{i, t, b e f o r e}$ across the foreign firms and the matched US samples and expect the association to be weaker for foreign firms (i.e., $\beta_{1 \text {, Foreign firm }}<$ $\beta_{1, \text { Matched US firm }){ }^{20}}$

Panel A of Table 5 presents univariate evidence on the restatement probability using ICMW indicator to identify firms with and without ICMWs. In each sample, firms with a ICMW are always more likely to restate than those that report no ICMW. More importantly, the differences in restatement probability between firms with and without ICMW are strongly related to home country enforcement. The weak RoL sample (matched US sample) shows a 5.22\% (19.25\%) difference in the restatement probability for firms with and without an ICMW. This difference increases to $12.60 \%(34.76 \%)$ for the strong RoL group (corresponding US matched sample).

Table 5, Panel B presents the results of estimating equation (3). Column (1) shows the estimated coefficients for all US-listed foreign firms and the US matched sample. For both samples, ICMWs are related to restatements, but the relation is stronger for the US sample (Ftest, $\mathrm{p}$-value $=0.01$ ), suggesting that foreign firms' restatements are less sensitive to ICMW than

\footnotetext{
${ }^{20}$ It is possible that ICMW reporting is also subject to the strength of detection and reporting incentives, i.e., the two step reporting process. If factors that drive the reluctance to report ICMWs are correlated with home country RoL, our findings may be subject to measurement error. Gong et al. (2012) show that the effect of home country enforcement on ICMW disclosure was significantly reduced after SOX 404, in effect since 2007, when Section 404 IC assessment by the auditor became mandated for all accelerated filers. In untabulated analysis we find no post-2007 effect of RoL on ICMW reporting. Thus, we restrict our sample period to after 2007. In additional analyses, we show that our findings are not driven by potential measurement error in the ICMW variable (see Section V). We cannot however fully discount the possibility that biases in ICMW reporting affect our results.
} 
those of comparable US firms. We interpret the lower sensitivity as evidence of less stringent detection/disclosure of accounting misstatements for the foreign sample relative to US firms. ${ }^{21}$

Column (2) shows the estimated coefficients for US listed firms from weak RoL countries and their matched sample. For weak RoL countries, there is no significant relation between $I C M W$ and restatement probability $($ coef. $=0.587, \mathrm{p}$-value $=0.259$ ), while the relation is positive and significant (coef. $=2.038$, p-value $<0.001$ ) for the US matched sample. In economic terms, having an ICMW increases the probability of restatement from $1 \%$ to $3.7 \%$ for firms from weak RoL countries compared to increase from $2.7 \%$ to $21.3 \%$ for comparable U.S. firms. ${ }^{22}$ The F-test shows that the difference in the coefficients is statistically significant ( $\mathrm{p}$-value $=0.043$ ). Column (3) results show that $I C M W$ is a strong predictor of restatements for both the strong RoL sample and its matched US sample. The F-test shows that the relationship is stronger for US companies than it is for companies from strong RoL countries. The results imply that firms' likelihood of detecting and reporting existing accounting problems increases with the home country RoL. ${ }^{23}$

\section{The Home Country Effect and Restatements Related to Accounting Irregularities}

One possible explanation for the lower restatement rate in weak RoL country-firms is that these firms avoid restating minor errors and report only accounting irregularities. While results in Table 4 suggest that weak RoL country-firms report fewer restatements related to accounting irregularities, we directly test for the difference in detection using the following model.

Restatement irregularities $\mathrm{s}_{\mathrm{i}, \mathrm{t}}=\beta_{0}+\beta_{1} \times \mathrm{EM}$ Index $_{\mathrm{i}, \mathrm{t}, \mathrm{before}}+\beta_{2-13}$ Firm Controls $_{\mathrm{i}, \mathrm{t}-1}$

$$
+\beta_{14-16} \text { Country Controls }_{\mathrm{c}, \mathrm{t}-1}+\text { Industry FE }+ \text { Year FE }+\varepsilon_{\mathrm{i}, \mathrm{t}}
$$

\footnotetext{
${ }^{21}$ Note that the reporting discretion of non-US firms is gauged relative to US firms. Since we cannot observe the true underreporting rate of any group of firms, we cannot make inferences about the absolute levels of underreporting.

${ }^{22}$ To compute the predicted probabilities, we evaluate each coefficient at the mean of the respective samples and calculate the predicted probability as $1 /(1+$ exponent of the negative summed value).

${ }^{23} \mathrm{We}$ also compare the restatement-ICMW sensitivity for the weak and strong RoL samples (i.e., within the foreign sample). Unreported F-test shows that the ICMW coefficient in the strong RoL sample is significantly higher than in the weak RoL sample when the two samples are compared with each other ( $p$-value <0.039).
} 
There are two differences between equation (4) and equation (3). First, we limit the sample to restatements related to accounting irregularities. The dependent variable Restatement irregularities $_{i, t}$ equals 1 if the financials for firm $i$ in year $t$ were restated due to an accounting irregularity, and zero otherwise. We define restatements related to accounting irregularities in two ways: restatements involving an external (SEC, DOJ) or internal (board of directors) investigation, and next based on ex ante classification as those involving core versus non-core items (Palmrose et al. 2004). Second, we use the EM Index instead of ICMW as the predictor. The EM Index is likely to predict accounting irregularities because earnings management implies that there was an intent to commit accounting mistakes (Dechow, Ge, Larson, and Sloan 2011). Because we omit the $I C M W$ variable, the sample for this test starts from 2000 instead of 2007.

We estimate equation (4) as a SUR model to compare estimates on our variable of interest, the $\beta_{1}$ coefficients, across the foreign firms and their matched US sample. To the extent that earnings management in firms from weak RoL countries is less likely to be revealed through restatements, we expect the $\beta_{l}$ coefficient to be less positive for such firms relative to US firms.

Table 6, Panel A presents the results of the logistic regression of equation (4), where Restatement irregularities is defined as restatements involving an internal or external investigation. Panel B shows our results using the ex ante definition, i.e., restatements involving core items following Palmrose et al. (2004).

In Panel A, column (1), we estimate the model using the foreign firm and the US matched samples. The estimated coefficient on the EM index shows that there is a significant relation between earnings management and restatement probability in the US matched firm sample, but not in the foreign sample. The F-test, however, shows that the difference between the two coefficients is not statistically significant. Next, we divide the foreign firms into those from 
strong vs. weak RoL countries and compare the EM index coefficient to the estimates from their respective matched US samples. Column (2) estimates a SUR model using the weak RoL firms and their US matched sample. The EM Index coefficient is positive and significant only for the US matched sample $(=0.219$, p-value $=0.006)$, but not for the foreign firm sample. F-tests show that the difference in the coefficients is statistically significant (p-value $=0.052$ ). Column (3) shows results using the strong RoL country sample and its matched US sample. The coefficient on EM Index is positive and significant for both the strong RoL and US matched sample; the difference in coefficients is not statistically significant ( $p$-value $=0.591)$. We find generally similar results in Panel B using core items to classify accounting irregularities.

The results suggest that, relative to similar US firms, restatements by firms from weak RoL countries are not as reflective of underlying accounting properties as they are for firms from strong RoL countries. ${ }^{24}$ The tendency of high EM firms to report irregularity type restatements is weakest for foreign firms with weak enforcement. This suggests that avoidance of restatements is true even for restatements that likely reflect irregularities as opposed to minor errors.

\section{Sensitivity Analysis}

\section{Measurement Error in the Reporting of Internal Control Weaknesses}

A potential concern with our tests is the measurement error in the $I C M W$ variable as a proxy for the likelihood of accounting misstatements. Firms have discretion in both ICMW reporting and restatement reporting are a choice variable for a firm. Thus, factors that drive ICMW reporting can also affect restatement outcomes. While we include various control variables to account for this effect, it is possible that our empirical model suffers from a misspecification,

\footnotetext{
${ }^{24}$ In untabulated analysis, we compare the two foreign samples of strong and weak rule of law firms to each other, without the matched US firm sample. An F-test shows that the coefficient on the EM variable in the strong RoL sample is significantly higher than in the weak RoL sample ( $\mathrm{p}$-value $=0.0084$ ).
} 
especially if the measurement error in ICMW systematically varies with RoL. To mitigate this concern we take the following three approaches.

First, we check if ICMW varies across strong versus weak RoL countries by regressing ICMW on RoL and other control variables (as in Table 4). In untabulated results, we find an insignificant coefficient on RoL suggesting that ICMW reporting is not systematically different across weak and strong RoL countries. This alleviates the concern that both restatements and ICMW vary by RoL. Second, we clarify that what we infer from the association between restatements and ICMWs is the incremental discretion in restatement reporting. Once a firm reports an ICMW, observing a lower restatement rate represents greater discretion in restatement reporting. In other words, our null hypothesis is that conditional on firms that report ICMW, the likelihood of restatements is similar across countries in the absence of discretion in restatement reporting. Therefore, an assumption underlying our empirical tests is that the relative discretion in the reporting of restatements is incrementally greater than the discretion in ICMW reporting. ${ }^{25}$

Third, we run additional tests using an alternative measure of ICMW which is not subject to a firm's reporting discretion - predicted ICMW. We estimate predicted ICMW using the prediction model from prior literature (Ashbaugh-Skaife et al. 2008; Doyle et al. 2007; Rice and Weber 2012). Specifically, we include in the model firm size, firm age, presence of losses, extreme sales growth, M\&A indicator, restructuring changes, acquisition activities in the prior

\footnotetext{
${ }^{25}$ Prior literature provides potential reasons why discretion in restatement reporting is greater than discretion in ICMW reporting. Studies show that while ICMWs have information content and are useful disclosures, restatements have a significantly greater negative impact on the firm than do ICMWs. Such negative consequences of restatements can provide greater incentives to managers and auditors to exercise discretion in restatement reporting. For example, Beneish, Billings, and Hodder (2008) show that section 404 ICMW disclosures have "no noticeable impact on stock prices or firms' cost of capital" (p. 665). Similar Ogneva, Raghunandan, and Subramanyam (2007) show that internal control weakness reports are not directly associated with higher cost of equity. Asbaugh-Skaife et al. (2009) do show that IC weaknesses are associated with higher cost of equity but their sample includes both SOX 302 and 404 cases. These findings are in stark contrast to the restatements studies that show a strong negative market reaction and higher cost of equity effect following restatements (Palmrose et al. 2004).
} 
year, foreign currency adjustments, CEO or CFO turnover in the previous year, stock/debt issuance in the prior year, ICMW in the prior year, restatement in the prior year, audit fees, nonaudit fees, Big 5 auditor, and auditor resignation. The estimated coefficients (untabulated) show that larger firms and firm-years with losses, M\&A, and auditor resignation are more likely to report an ICMW. We calculate the fitted probabilities and estimate the predicted probabilities as an indicator variable. ${ }^{26}$

We repeat our analysis in Table 5 (untabulated) using the the predicted ICMW variable. We find that the relation between predicted ICMW and restatement probability is positive and significant for US firms (coef. $=0.974, \mathrm{p}$-value $=0.056$ ), while the relation is negative (coef. $=$ 1.430, $\mathrm{p}$-value $=0.018$ ) for firms from weak RoL countries. The F-test shows that the difference in the weak RoL firms and the US sample is significant. For the strong RoL sample and its matched US sample, predicted ICMW is a strong predictor of restatements but with no significant difference between the two samples. This suggests that our findings are robust to using an alternative measure of ICMW.

\section{Restatement Frequency: Excluding Quarterly Restatements}

One possible reason for fewer restatements by foreign firms is the difference in quarterly reporting rules. Foreign registrants do not have a dedicated form like the 10-Q for quarterly financials (they use form 6-K) and do not have to report quarterly if they do not do so in the home country. We examine the robustness of Table 5 results after excluding quarterly restatements. Results (untabulated) lead to similar inferences as in Table 5. In all three columns (US vs foreign, weak RoL vs US matched, and strong RoL vs US matched) the ICMW coefficient is positive and

\footnotetext{
${ }^{26}$ For the indicator variable, we cut the fitted probability at the point where the sensitivity and the inverse of the specificity of the ROC curve are jointly maximized. The numerical value of this cut-off point is 0.05 . We use the country sample median of the rule of law index $(=1.64)$ to classify firms as from strong or weak rule of law countries.
} 
significantly higher for the US sample than the corresponding foreign sample. The weak RoL sample does not show a significant coefficient on ICMW indicating that ICMW is not a predictor of restatements in weak RoL countries unlike in the US and strong RoL countries. We conclude that the lack of quarterly filing rules do not explain the lower restatement rate of foreign firms.

\section{ADDITIONAL ANLAYSES}

\section{IFRS Adoption in the Home Country and Likelihood of Restatements}

The RoL measure is a static variable and does not consider changes in institutions over time. In this section, we use the mandatory adoption of IFRS as a proxy for time series changes in the quality of accounting institutions in the home country. ${ }^{27}$ Prior research suggests that IFRS adoption is associated with higher reporting quality (Barth, Landsman, and Lang 2008) and a significant reduction in information asymmetry (Daske, Hail, Leuz, and Verdi 2008; Wahid and $\mathrm{Yu}$ 2014). Further, the variation in whether and when different countries adopt IFRS allows us to examine the IFRS effect controlling for other concurrent changes affecting all foreign firms.

We examine the changes in the association between EM and restatement likelihood postIFRS for foreign firms in weak and strong RoL countries. ${ }^{28}$ We obtain from Daske et al. (2008) the list of countries that adopt IFRS and their adoption years. We estimate equation (4) with two additional terms. We include a dummy variable (Post IFRS) for the years after IFRS and an interaction term (Post IFRS $\times$ EM Index), which is our main variable of interest examining the marginal increase in the association between EM and restatement likelihood following IFRS.

\footnotetext{
${ }^{27}$ Many foreign firms in our sample use US GAAP. To the extent home country IFRS adoption improves the quality of domestic accounting institutions, we expect IFRS adoption to improve outcomes even for US GAAP users.

${ }^{28}$ We cannot conduct this test using ICMW because the ICMW sample begins only after 2007, reducing the variation in IFRS adoption which mostly occurred before 2007. Majority of the IFRS adopting countries first mandated IFRS in 2005 .
} 
Table 7 presents the results for foreign firms from weak and strong RoL countries. We find that the effect on the Post IFRS variable is negative and significant only for the strong RoL firms (coef.=-1.699, p-value $=0.028$ ). For the weak RoL firms, the estimated coefficient is negative but not significant. The lower restatement rates following IFRS adoption may suggest fewer irregularities in the reported financials but may also suggest a lack of detection of existing accounting irregularities. We next examine the extent of stringent detection triggered by IFRS adoption by evaluating association of restatements to the EM index following IFRS adoption.

The interaction term (Post IFRS $\times$ EM Index) examines whether the association between EM and restatement likelihood increased after IFRS adoption. Table 7 shows that the coefficient on the interaction term is positive and significant (coef. $=-0.561$, $p$-value $=0.04$ ) for only the firms from weak RoL countries. This is not surprising since for the strong RoL firms the association between EM and restatement likelihood was not significantly different from that of US firms in Table 6. The finding suggests that IFRS adoption had a greater impact on improving the reliability of restatement reporting for foreign firms from weaker RoL countries.

However, we note that even after IFRS adoption, there remain significant differences in the overall restatement-EM sensitivity between the strong and weak RoL firms. Despite the incremental increase in the weak RoL firms following IFRS adoption, the F-tests show that the sum of EM index and Post IFRS $\times$ EM Index is positive and significant for only the strong RoL firms $(F-s t a t=4.19, p$-value $=0.041)$ while insignificant for the weak RoL firms $(p$-value $=0.131)$. Taken together, the results suggest that while IFRS adoption in the home-country led to an 
incremental increase in the reliability of restatement reporting, the home country-effect continued to affect the reporting behavior of all foreign firms even after IFRS adoption. ${ }^{29}$

\section{The Restatement Disclosure Method Choices of Foreign Firms Listed in the US}

Prior studies show that, conditional on reporting a restatement, firms make disclosure choices regarding the announcement medium to minimize the cost of restating (Files et al. 2009; Myers, Scholz, and Sharp 2010; Badertscher and Burks 2011). While our main focus is on the likelihood of restatement, we also examine whether foreign firms differ in the disclosure method.

All firms are required to correct previous errors in their financials in their regular filings (10-K, 10-Q, 20-F, or 40-F). In addition to the regular filings, the SEC requires the restatements that are deemed "material" to be separately disclosed using a Form 8-K (or 6-K for foreign firms) (SEC 2004). Many firms also voluntarily issue press releases describing the error and its financial impact. Restatements announced using additional disclosure media (using an 8-K, 6-K, or press release) are presumably more visible and draw investor attention on a timely basis. In contrast, restatements that are considered immaterial are reported only in regular filings, which are less visible and available at the next regular filing date. ${ }^{30}$

We examine opportunism in restatement disclosure by examining the association between the restatement's materiality and the use of a visible disclosure medium. If foreign firms are opportunistic, they will be less likely than the matched U.S. firms to report material restatements using visible disclosure media. We test this prediction using the following model: ${ }^{31}$

\footnotetext{
${ }^{29}$ Prior studies find an increase in the number of restatements since passage of SOX (Burks 2011). We examine whether SOX led to changes in the association between EM and restatement likelihood. In untabulated analysis, we find that while the association between restatement and EM increased following SOX, there are no significant differences across firms from weak vs. strong rule of law countries.

${ }^{30}$ However, there could be cases where the next regular filing (e.g., 10-K) is the speediest form of communication e.g., if the next $10-\mathrm{K}$ is scheduled within 2 weeks. An $8-\mathrm{K}$ filing is still necessary to indicate that prior financial statements should not be relied upon (see Taub 2012).

${ }^{31}$ Given the small number of observations for this test, we do not include industry and year fixed effects.
} 
Visible restatement $_{\mathrm{i}, \mathrm{t}}=\beta_{0}+\beta_{1}$ Materiality $_{\mathrm{i}, \mathrm{t}}+\beta_{2-13}$ Firm Controls $_{\mathrm{i}, \mathrm{t}-1}+\beta_{14-16}$ Country Controls $_{\mathrm{i}, \mathrm{t}-1}+\varepsilon_{\mathrm{i}, \mathrm{t}}$.

The dependent variable, Visible restatement ${ }_{i, t}$, equals 1 if the restatement is reported with a separate filing (e.g., 8-K or a press release), in addition to the regularly scheduled financials, and zero otherwise (Files et al. 2009). Materiality is an indicator variable that equals one if the restatement is material, zero otherwise. We follow prior literature and gauge materiality using both quantitative and qualitative measures. We first define material restatements as those that have a greater than 5\% net income impact (Nelson, Elliott, and Tarpley 2005). We also consider qualitative measures and define restatements as material if there is likely to be an intent (Acito, Burks, and Johnson 2009). We measure intent based on restatements (i) where the error changes a loss into profit, (ii) that reverse an increase in earnings trend from prior years, (iii) are issued in periods of high financial distress, defined as firm-years in the highest leverage decile, or (iv) related to the core accounts.

While the SEC limits the use of less visible disclosure for restatements deemed material, not all foreign firms are subject to this requirement. ${ }^{32}$ To ensure that our findings are not driven by differences in disclosure requirements between US and foreign firms, we limit our foreign firm sample to those that file $10-\mathrm{Ks}$ and are therefore subject to reporting requirements identical to those of US firms. ${ }^{33} \mathrm{We}$ also control for the firm's tendency to issue press releases using the average annual number of press releases issued by the firm, starting from the first year the firm appears in our sample up to the current year (Previous press releases).

\footnotetext{
${ }^{32}$ For example, foreign firms filing a 20-F or 40-F are not required to file 8-Ks. These firms instead furnish current reports on form $6-\mathrm{K}$ for timely disclosure of a material event . Unlike filed 8-Ks, which hold the preparer liable for any false or misleading information, 6-Ks are furnished, holding the preparer liable only when the preparer is proven to have 'intentionally' provided false or misleading information. Filed information is subject to the liability provisions of Section 18 of the Exchange Act of 1934 and is automatically incorporated into issuers' registration statement. Furnished information is not subject to the same liability section and is not automatically incorporated into the registration statement, unless the issuer specifically requests its incorporation.

${ }^{33}$ Foreign firms that list directly on US markets or that do not qualify for foreign issuer status have to file their financials using the same forms as US firms.
} 
Table 8 presents the results of estimating equation (5) as a SUR model to compare the coefficient estimate for foreign firms and their US matched sample. The main variable of interest is the coefficient on materiality $\left(\beta_{1}\right)$. Results show that the association between materiality and visible disclosure varies systematically across the foreign and US samples. ${ }^{34}$ Column (1) shows that the $\beta_{1}$ coefficient is positive and statistically significant only for the US sample and insignificant for the foreign sample. The difference in the coefficients, however, is not statistically significant. In column (2), we consider qualitative measures of materiality. For foreign firms, the association between materiality and visible disclosure is insignificant, while for the US sample, the association is positive and statistically significant (coef.=1.691, p-value=0.005). The difference between the two is statistically significant ( $p$-value=0.041), suggesting that the use of visible disclosure medium for qualitatively material restatement is greater for US firms.

\section{CONCLUSION}

We study restatements by US listed foreign firms, compare the extent of restatements by these firms with that of domestic US firms, and examine the role of home country characteristics in the likelihood of the foreign firms issuing restatements. On the one hand, restatements reflect weakness in financial reporting. On the other hand, a restatement announcement implies that the accounting error or irregularity was identified and corrected, indicating that internal and external governance mechanisms (such as internal controls and external audits) performed their expected roles. Results in the paper suggest that foreign firms listed in the US restate less than comparable US firms despite the foreign firms having weaker accounting quality. The results suggest that such difference can be attributed to avoidance of reporting restatements. The difference with US firms is driven primarily by firms from countries with weaker legal institutions.

\footnotetext{
${ }^{34}$ In untabulated multivariate analysis, we examine the intercept effect. The difference in the likelihood of visible restatements for US listed foreign firms and the matched US firms is not statistically significant ( $\mathrm{p}$-value $=0.870$ ).
} 
Our results suggest that foreign firms listed in the US are subject to less rigorous monitoring and enforcement than are domestic US firms. Further, weaker institutions in the firm's home country reduces compliance with US reporting rules for foreign firms accessing US markets, despite a common set of US rules that apply to them upon a US listing. Therefore, compared to US firms, restatements are a less accurate measure of reporting problems for non-US firms.

The finding that foreign firms show less reliable detection and reporting of errors and irregularities raises concerns for investor and regulators. Restatements are an admission by the company of errors or irregularities in financial statements. Therefore, they are valuable to investors and regulators as an information mechanism for holding managers accountable for misreporting. Thus, a lack of reliable restatement reporting increases the cost for investors and regulators to monitor firms. The broader implication is that the lower frequency of restatements implies less ex post penalties, which reduces the ex ante discipline in financial reporting. 


\section{REFERENCES}

Acito, A., J. Burks, and B. Johnson. 2009. Materiality decisions and the correction of accounting errors. The Accounting Review 84 (3): 659-88.

FASB Accounting Standards Codification Topic 250 Accounting Changes and Error Corrections, available online: https://asc.fasb.org.

Ashbaugh-Skaife, H., D. Collins, W. Kinney, and R. Lafond. 2008. The effect of SOX internal control deficiencies and their remediation on accrual quality. The Accounting Review 83: 217-5.

Badertscher, B., and J. Burks. 2011. Accounting restatements and the timeliness of disclosures. The Accounting Horizons 25(4):609-630.

Badertscher, B., J. Phillips, M. Pincus, and S. Rego. 2009. Earnings management strategies and the tradeoff between tax benefits and detection risk: To conform or not to conform? The Accounting Review 84 (1): 63-97.

Bae, K. H., H. Tan, and M. Welker. 2008. International GAAP differences: The impact on foreign analysts. The Accounting Review 83: 593-628.

Ball, R., S. Kothari, and A. Robin. 2000. The effect of international institutional factors on properties of accounting earnings. Journal of Accounting \& Economics 29: 1-51.

Barth, M., W. R. Landsman, and M. H. Lang. 2008. International accounting standards and accounting quality. Journal of Accounting Research 46: 467-498.

Beatty, A., S. Liao, and J.J Yu. 2013. The spillover effect of fraudulent financial reporting on peer firms' investments. Journal of Accounting and Economics 56:183-205.

Beneish, M.D, Mary B. Billings, Leslie D. Hodder. 2008, Internal Control Weaknesses and Information Uncertainty. The Accounting Review: 665-703.

Brochet, F., and S. Srinivasan. 2013. Accountability of independent directors: Evidence from firms subject to securities litigation. Journal of Financial Economics 111: 430-449.

Burgstahler, D., and I. Dichev. 1997. Earnings management to avoid earnings decreases and losses. Journal of Accounting and Economics 24: 99-126.

Burks, J. J. 2011. Are investors confused by restatements after Sarbanes-Oxley? The Accounting Review 86(2): 507-539.

Bushman, R.M., and A.J. Smith. 2001. Financial accounting information and corporate governance. Journal of Accounting and Economics 1-3: 237-333.

Chakravarthy, J., E. DeHaan and S. Rajgopal. 2013. Reputation repair after a serious restatement. The Accounting Review (forthcoming).

Cheng, B., S. Srinivasan, and G. Yu. 2013. Securities Litigation Risk for Foreign Companies Listed in the U.S. Working paper, Harvard Business School. 
Choi, J-H, J-B Kim, X. Liu, and D.A. Simunic. 2009. Cross-listing audit fee premiums: Theory and evidence. The Accounting Review 84 (5):1429-1463.

Coffee, J. Jr. 2002. Racing towards the top?: The impact of cross-listings and stock market competition on international corporate governance. Columbia Law Review 102: 1757-1831.

Collins, D., A. Masli, A. L. Reitenga, and J. M. Sanchez. 2009. Earnings restatements, the Sarbanes-Oxley Act, and the disciplining of chief financial officers. Journal of Accounting, Auditing \& Finance 24 (1): $1-34$.

Daske, H., L. Hail, C. Leuz, and R. Verdi. 2008. Mandatory IFRS reporting around the world: Early evidence on the economic consequences. Journal of Accounting Research 46: 1085-1142.

Dechow, P. M., and I. D. Dichev. 2002. The quality of accruals and earnings: The role of accrual estimation errors. The Accounting Review 77: 35-59.

Dechow, P. M., W. Ge, C. R. Larson, and R. G. Sloan. 2011. Predicting material accounting misstatements. Contemporary Accounting Research 28:17-82.

Dechow, P. M., W. Ge, and C. Schrand. 2010. Understanding earnings quality: A review of the proxies, their determinants and their consequences. Journal of Accounting and Economics 50: 344-401.

DeFond, M. L., and J. Jiambalvo. 1991. Incidence and circumstances of accounting errors. The Accounting Review 66: 643-655.

DeHaan, E., Hodge, F. D., and Shevlin, T. J. 2012. Does voluntary adoption of a clawback provision improve financial reporting quality? Contemporary Accounting Research 30:1027-1062.

Desai, H., C. E. Hogan, and M. S. Wilkins. 2006. The reputational penalty for aggressive accounting: Earnings restatements and management turnover. The Accounting Review 81: 83-112.

Doidge, C. 2004. U.S. cross-listings and the private benefits of control: Evidence from dual-class firms. Journal of Financial Economics 72: 519-553.

Doidge, C., G. A. Karolyi, and R. M. Stulz. 2007. Why do countries matter so much for corporate governance? Journal of Financial Economics 86 (1): 1-39.

Doyle, J., W. Ge, and S. McVay. 2007. Accruals quality and internal control over financial reporting. The Accounting Review 82: 1141-1170.

Dyck, A., A. Morse, and L. Zingales. 2010. Who blows the whistle on corporate fraud? Journal of Finance 65: 2213-2253.

Files, R., E. Swanson, and S. Tse. 2009. Stealth disclosure of accounting restatements. The Accounting Review 84: 1495-1520.

Francis, J., R. LaFond, P. Olsson, and K. Schipper. 2005. The Market pricing of accruals quality. Journal of Accounting and Economics 39: 295-327.

Frost, C. A., and G. Pownall. 1994. Accounting disclosure practices in the United States and the United Kingdom. Journal of Accounting Research 32: 75-102. 
Generally accepted accounting principles (GAAP). 2001. A Survey of National Accounting Rules Benchmarked Against International Accounting Standards. Available online: http://www.iasplus.com/en/resources/binary/resource/gaap2001.pdf.

Gong, G., B. Ke, and Y. Yu. 2012. Home country investor protection, ownership structure and cross-listed firms' compliance with SOX-mandated internal control deficiency disclosures. Contemporary Accounting Review (forthcoming).

Hammersley, J., L. Myers, and C. Shakespeare. 2008. Market reactions to the disclosure of internal control weaknesses and to the characteristics of those weaknesses under Section 302 of the SarbanesOxley Act of 2002. Review of Accounting Studies 13: 141-165.

Heitzman, S., C. Wasley, and J. Zimmerman. 2010. The joint effects of materiality thresholds and voluntary disclosure incentives on firms' disclosure decisions. Journal of Accounting and Economics 49: 109-132.

Hennes, K. M., A. J. Leone, and B. P. Miller. 2008. The importance of distinguishing errors from irregularities in restatement research: The case of restatements and CEO/CFO turnover. The Accounting Review 83: 1487-1519.

Hope, O-K., T. Kang, and J. W. Kim. 2012. Voluntary disclosure practices by foreign firms cross-listed in the United States. Journal of Contemporary Accounting and Economics (forthcoming).

Jenkins, E. 1999. Financial reporting in a global capital market world. Financial Accounting Series, No. 198-A (June 29): 2-6.

Johnson, M. F., Nelson, K. K., Pritchard, A. C., 2007. Do the merits matter more? The impact of the Private Securities Litigation Reform Act." Journal of Law, Economics \& Organization, 23, 627652.

Karolyi, G.A. 2006. The world of cross-listings and cross-listings of the world: Challenging conventional wisdom. Review of Finance 10: 99-152.

Karpoff, J.M., D.S. Lee, and G.S. Martin. 2008. The cost to firms of cooking the books. Journal of Financial and Quantitative Analysis 43: 581-611.

Kaufmann, D., A. Kraay, and M. Mastruzzi. 2003. Governance matters III: Governance indicators for 1996-2002. World Bank Policy Research Working Paper 3106.

Kedia, S., and T. Philippon. 2009. The economics of fraudulent accounting. Review of Financial Studies 22: 2169-99.

Keune, M., and K., Johnstone. 2012. Materiality judgments and the resolution of detected misstatements: The role of managers, auditors, and audit committees. The Accounting Review 87:1641-1677.

La Porta, R., F. Lopez-de-Silanes, A. Shleifer, and R. Vishny. 1998. Law and finance. Journal of Political Economy 106: 1113-55.

La Porta, R., F. Lopez-De-Silanes, and A. Shleifer. 2006. What works in securities laws? The Journal of Finance 61: 1-32. 
Lang, M., J. S. Raedy, and W. Wilson. 2006. Earnings management and cross listing: Are reconciled earnings comparable to US earnings? Journal of Accounting and Economics 42: 255-283.

Leuz, C., D. Nanda, and P. D. Wysocki. 2003. Earnings management and investor protection: An international comparison. Journal of Financial Economics 69: 505-527.

Myers, L.A., S. Scholz, and N.Y. Sharp. 2010. Restating under the radar? Determinants of restatement disclosure choices and the related market reactions. SSRN eLibrary.

Nelson, M., J. Elliott, and R. Tarpley. 2005. A review of experimental and archival conflicts-of-interest research in auditing. In: Conflicts of Interest: Challenges and Solutions in Business, Law, Medicine, and Public Policy 41-69. New York : Cambridge University Press.

Ogneva, M., K. Raghunandan, and K. R. Subramanyam. 2007. Internal control weakness and cost of equity: Evidence from SOX Section 404 certifications. The Accounting Review 82: 1255-1297.

Palmrose, Z.V., and S. Scholz. 2004. The circumstances and legal consequences of Non-GAAP reporting: Evidence from restatements. Contemporary Accounting Research 21 (1): 139-180.

Palmrose, Z.V., V. J. Richardson, and S. Scholz. 2004. Determinants of market reactions to restatement announcements. Journal of Accounting \& Economics 37: 59-89.

Plumlee, M., and T. Yohn. 2010. An analysis of the underlying causes attributed to restatements. Accounting Horizons 24: 41-64.

Rice S. C. and Weber, D. P. 2012 How Effective Is Internal Control Reporting under SOX 404? Determinants of the (Non-)Disclosure of Existing Material Weaknesses. Journal of Accounting Research 50: 811-843.

Richardson, S., Y. Tuna, and M. Wu. 2002. Predicting Earnings Management: The Case of Earnings Restatements. London Business School Working paper.

Securities and Exchange Commission (SEC). 2004. Final Rule: Additional Form 8-K Disclosure Requirements and Acceleration of Filing Date. Release No. 33-8400; 34-49424; File \#. S7-22-02.

Seetharaman, A., F. A. Gul, and S. G. Lynn. 2002. Litigation risk and audit fees: Evidence from U.K. firms crosslisted on U.S. markets. Journal of Accounting and Economics 33 (1): 91-115.

Srinivasan, S. 2005. Consequences of financial reporting failure for outside directors: Evidence from accounting restatements and audit committee members. Journal of Accounting Research 43: 291334.

Standard and Poor's Global Stock Markets Factbook 2010. Available online: http://www.standardandpoors.com/products-services/global-stock-markets-factbook/en/us

Wahid, A. S., and G. Yu. 2014. Accounting Standards and International Portfolio Holdings. The Accounting Review, forthcoming.

Wysocki, P. D. 2009. Assessing Earnings and Accruals Quality: U.S. and International Evidence. University of Miami Working paper. 
APPENDIX: VARIABLE DEFINITIONS ( $\mathrm{i}=$ firm, $\mathrm{c}=$ country, $\mathrm{r}=$ restatement, $\mathrm{t}=$ =year)

\begin{tabular}{|c|c|}
\hline Variable & Description \\
\hline $\begin{array}{l}\text { Earnings management } \\
\text { EMI } 1_{i, t, p r i o r} \\
: \% \text { of firm-years with } \\
\text { small positive income }\end{array}$ & $\begin{array}{l}\% \text { of firm-years that have a small positive income. Small positive income is defined } \\
\text { as years where net income scaled by total assets (all using unrestated numbers) falls } \\
\text { between } 0 \text { and } 0.01 \text {. For each firm-year, we calculate the percentage of years with } \\
\text { small positive income using the last three years; the current fiscal year }(\mathrm{t} \text { ), the } \\
\text { previous fiscal year (t-1) and two years before }(\mathrm{t}-2) \text {. The subscript } \mathrm{t}-1 \text { denotes that } \\
\text { the measure represents values prior to identifying the need to restate the year } t \\
\text { financials. }\end{array}$ \\
\hline $\begin{array}{l}E M 2_{i, t, p r i o r} \\
\mid \text { Accruals }|\Lambda C F O|\end{array}$ & $\begin{array}{l}\text { The magnitude of total accruals measured as the ratio of the absolute value of total } \\
\text { accruals to the absolute value of operating cash flows (Leuz et al. 2003) in the } \\
\text { current fiscal year, t. The magnitude of the total accruals is used as a proxy for } \\
\text { managerial discretion and scaled by operating cash flows to adjust for the } \\
\text { differences in firm economics. Total accruals are calculated using the unrestated } \\
\text { financials and defined as ( } \Delta \text { Current Assets - } \Delta \text { Cash) - ( } \Delta \text { Current Liabilities - } \\
\Delta \text { Current Debt - } \Delta \text { Tax Payable) - } \Delta \text { Depreciation following Dechow et al. (1995). }\end{array}$ \\
\hline $\begin{array}{l}\text { EM3 } \\
\text { : Act,prior } \\
\text { Accruals quality }\end{array}$ & $\begin{array}{l}\text { The standard deviation of the residual from a firm-level regression of current } \\
\text { accruals on prior and future operating cash flow (Dechow and Dichev, 2002; } \\
\text { Wysocki 2009) using the unrestated financials. The measure captures the estimation } \\
\text { errors in the accruals process by estimating how well accruals map into cash flows. } \\
\text { The regression model is estimated cross-sectionally each year for each industry } \\
\text { (two-digit SIC-code). }\end{array}$ \\
\hline $\begin{array}{l}\text { EM4 } 4_{i, t, p r i o r} \\
:-\operatorname{Corr}(\triangle A c c r u a l, \triangle C F O)\end{array}$ & $\begin{array}{l}\text { The correlation between changes in accruals and operating cash flows multiplied by } \\
\text { negative one. The negative correlation is a discretionary smoothing measure which } \\
\text { proxies for management intervention over and above the natural level of accruals } \\
\text { accounting (Francis et al. 2005). We use the unrestated figures and calculate the } \\
\text { correlation between the changes in accruals and operating cash flows using the last } \\
\text { three years. }\end{array}$ \\
\hline EM Index i,t,prior & $\begin{array}{l}\text { Average percentile rank for each firm for the year across the four (or as many as are } \\
\text { available) measures of earnings management in the current fiscal year. The subscript } \\
\text { prior denotes that the measure represents values prior to identifying the need to } \\
\text { restate the year t's financials, using unrestated numbers. Each year, all firms are } \\
\text { ranked on each measure and percentile rank is assigned to the firm for all four (or all } \\
\text { available) measures. Higher values indicate higher earnings management. }\end{array}$ \\
\hline $\begin{array}{l}\text { Firm charad } \\
\text { Size }_{i, t}\end{array}$ & of fisca \\
\hline Leverage $_{i, t}$ & Long term and short term debt, scaled by total assets at the end of fiscal year $\mathrm{t}$. \\
\hline$R O A_{i, t}$ & Income before extraordinary items scaled by total assets at the end of fiscal year $t$. \\
\hline Book-to-Market ${ }_{i, t}$ & Book to market ratio measured at the end of year t. \\
\hline Big Five Auditor $_{i, t}$ & $\begin{array}{l}\text { Indicator variable equal to } 1 \text { if the firm is audited by one of the Big } 5 \text { audit firms for } \\
\text { the fiscal year t, zero otherwise. }\end{array}$ \\
\hline Analyst coverage $_{i, t}$ & Number of analysts covering the firm at any point during the fiscal year $t$. \\
\hline Institutional ownership $_{i, t}$ & Percentage of float shares owned by US institutional investors at the end of year $\mathrm{t}$. \\
\hline Sales growth $_{i, t}$ & $\%$ increase in sales from fiscal year $\mathrm{t}-1$ to year $\mathrm{t}$. \\
\hline Segment $_{i, t}$ & Natural log of the number of the firm's business segments for the fiscal year t. \\
\hline Reporting Standard $_{i, t}$ & $\begin{array}{l}\text { Indicator variable equal to } 1 \text { if firms use US GAAP or IFRS without reconciliation } \\
\text { for fiscal year t, } 0 \text { if firms use local GAAP with reconciliation to US GAAP. }\end{array}$ \\
\hline$I C M W_{i, t, p r i o r}$ & $\begin{array}{l}\text { Indicator variable equal to } 1 \text { if the firm reported an internal control material } \\
\text { weakness (SOX section 404) for the year t, prior to identifying the need to restate } \\
\text { the financials, and zero otherwise. The subscript prior denotes that the measure } \\
\text { represents values prior to identifying the need to restate the year t's financials. We } \\
\text { use the original IC effectiveness report to focus exclusively on the ICMW prior to } \\
\text { the discovery of year t's restatement. }\end{array}$ \\
\hline
\end{tabular}




\section{APPENDIX: VARIABLE DEFINITIONS (CONTINUED)}

\begin{tabular}{|c|c|}
\hline Variable & Description \\
\hline $\begin{array}{l}\text { Previous press } \\
\text { releases }_{i, t}\end{array}$ & $\begin{array}{l}\text { Annual average of 8-k filings, measured over the time period starting with } 2000 \text { (or the } \\
\text { earliest year the firm appears in the sample) to the year of the restatement. }\end{array}$ \\
\hline \multicolumn{2}{|c|}{ Restatement characteristics } \\
\hline $\begin{array}{l}\text { Restatement } \\
\text { irregularities }_{r}\end{array}$ & $\begin{array}{l}\text { Indicator variable equal to } 1 \text { if the restatement is related to an accounting irregularity, } \\
\text { and zero otherwise. We define restatements related to severe accounting irregularities } \\
\text { using (i) ex post measures using external or board investigation (Hennes et al. 2008) } \\
\text { and (ii) ex ante measures using the core/non-core account classification (Palmrose et al. } \\
\text { 2004). Core accounts are those related to revenue recognition, cost of goods sold, } \\
\text { operating expenses, or depreciation. The classification uses restatement descriptions } \\
\text { provided in Audit Analytics. }\end{array}$ \\
\hline Core account ${ }_{r}$ & $\begin{array}{l}\text { Indicator variable equal to } 1 \text { if the restatement is related to either one of the following } \\
\text { accounts; revenue recognition, cost of goods sold, operating expenses, or depreciation, } \\
\text { and } 0 \text { otherwise (Palmrose et al. 2004). }\end{array}$ \\
\hline Visible restatement $_{r}$ & $\begin{array}{l}\text { Indicator variable equal to } 1 \text { if the restatement is reported with a separate filing (e.g., } \\
\text { form } 8-K \text { or } 6-K \text {, a press release, or non-timely filings such as NT } 10 \text {-K or equivalent) } \\
\text { in addition to the regularly scheduled financial statements, and zero otherwise. The } 6- \\
\text { Ks of foreign firms often include other filings unrelated to restatements (e.g., quarterly } \\
\text { results). We examine all } 6-K s \text { that announce a restatement to determine whether the } \\
\text { restatement announcement was issued alone, or in conjunction with quarterly results. }\end{array}$ \\
\hline Magnitude $_{r}$ & The dollar amount of equity restated, scaled by total assets. \\
\hline Material $_{r}$ & $\begin{array}{l}\text { Indicator variable equal to } 1 \text { if the restatement is deemed material, and } 0 \text { otherwise. We } \\
\text { define materiality using quantitative measures - those that have a greater than } 5 \% \text { net } \\
\text { income impact - and qualitative measures that capture the firms' intent - where the } \\
\text { restatement (i) changes a loss into profit, (ii) reverses an increase in earnings trend from } \\
\text { prior years, (iii) is issued in periods of high financial distress, defined as firm-years in } \\
\text { the highest leverage decile, or (iv) related to the core accounts. }\end{array}$ \\
\hline Time to discovery $r$ & $\begin{array}{l}\text { Number of months from the end of the restatement period to the day the restatement } \\
\text { was reported/discovered. }\end{array}$ \\
\hline Litigation $_{r}$ & $\begin{array}{l}\text { An indicator variable equal to } 1 \text { if there is an identified litigation related to the } \\
\text { restatement within one year after the restatement announcement, zero otherwise. }\end{array}$ \\
\hline SEC investigation $_{r}$ & $\begin{array}{l}\text { Indicator variable equal to one if an SEC investigation relating to the restatement is } \\
\text { identified by Audit Analytics, zero otherwise. }\end{array}$ \\
\hline Country characteristics & $\mathrm{n}$ indicator variable equal to 1 if the CEO leaves within a year of the restatement. \\
\hline Weak RoL & $\begin{array}{l}\text { Indicator variable equal to one if the rule of law index is below the country sample } \\
\text { median (=1.64). The rule of law index is from the Worldwide Governance Indicators } \\
\text { created by the World Bank (Kaufmann et al. (2003) and used in La Porta et al. (2006)). } \\
\text { Rule of law measures the extent to which agents have confidence in and abide by the } \\
\text { rules of society in the year 2000. These include perceptions of the incidence of both } \\
\text { violent and non-violent crime, the effectiveness and predictability of the judiciary, and } \\
\text { the enforceability of contracts. }\end{array}$ \\
\hline Accounting difference $_{c}$ & $\begin{array}{l}\text { Measure of the difference between two local accounting standards from Bae, Tan, and } \\
\text { Welker (2008) and modified in Wahid and Yu (2013). The measure is constructed } \\
\text { based on a survey examining the extent to which local accounting standards deviate } \\
\text { from US GAAP for a list of } 21 \text { accounting rules (GAAP 2001). Two rules are } \\
\text { considered similar when the rules of both countries comply with US GAAP. Two } \\
\text { countries that follow local standards that are not compliant with IFRS are considered to } \\
\text { have similar rules only if they derive from the same legal origin. }\end{array}$ \\
\hline Country market cap $c_{c, t}$ & $\begin{array}{l}\text { Market capitalization in } \$ \text { billion for country c at the end of year t, obtained from } \\
\text { Standard and Poor's Global Stock Markets Factbook } 2010 \text {. }\end{array}$ \\
\hline Country GDP grow & $\%$ GDP growth in the prior year, from year $\mathrm{t}-1$ to $\mathrm{t}$. \\
\hline Auditor liability $_{c}$ & Liability standard for accountant measure from La Porta et al. (2006). \\
\hline
\end{tabular}


TABLE 1: SAMPLE DESCRIPTIVE, 2000 - 2010

Panel A: Distribution of cross-listed firms and restatements by country of domicile, firms from weak rule of law countries

\begin{tabular}{|c|c|c|c|c|c|c|}
\hline $\begin{array}{l}\text { WEAK RULE OF LAW (RoL) } \\
\text { COUNTRIES }\end{array}$ & $\begin{array}{c}\text { (1) } \\
\text { \# of restatements } \\
\text { - total } \\
\end{array}$ & $\begin{array}{l}\text { (2) } \\
\text { \# of restatements related } \\
\text { to core accounts }\end{array}$ & $\begin{array}{l}\text { (3) } \\
\text { \# of restatements due to } \\
\text { accounting irregularities }\end{array}$ & $\begin{array}{c}\text { (4) } \\
\begin{array}{c}\text { \# of cross-listed } \\
\text { firm-years }\end{array} \\
\end{array}$ & $\begin{array}{c}(5)=(1) /(4) \\
\% \text { of restating } \\
\text { firm-years }\end{array}$ & $\begin{array}{c}(6)=(3) /(4) \\
\% \text { of restating firm-years, } \\
\text { accounting irregularities }\end{array}$ \\
\hline Argentina & 2 & 0 & 0 & 111 & $2 \%$ & $0 \%$ \\
\hline Brazil & 6 & 6 & 0 & 79 & $8 \%$ & $0 \%$ \\
\hline Chile & 2 & 2 & 0 & 160 & $1 \%$ & $0 \%$ \\
\hline China & 44 & 27 & 24 & 658 & $7 \%$ & $4 \%$ \\
\hline Colombia & 0 & 0 & 0 & 1 & $0 \%$ & $0 \%$ \\
\hline France & 17 & 9 & 1 & 222 & $8 \%$ & $0 \%$ \\
\hline Ghana & 0 & 0 & 0 & 3 & $0 \%$ & $0 \%$ \\
\hline Greece & 2 & 2 & 0 & 142 & $1 \%$ & $0 \%$ \\
\hline India & 5 & 5 & 1 & 102 & $5 \%$ & $1 \%$ \\
\hline Indonesia & 1 & 0 & 1 & 21 & $5 \%$ & $5 \%$ \\
\hline Israel & 19 & 13 & 2 & 756 & $3 \%$ & $0 \%$ \\
\hline Italy & 1 & 1 & 0 & 75 & $1 \%$ & $0 \%$ \\
\hline South Korea & 3 & 2 & 1 & 88 & $3 \%$ & $1 \%$ \\
\hline Malaysia & 0 & 0 & 0 & 1 & $0 \%$ & $0 \%$ \\
\hline Mexico & 3 & 3 & 0 & 197 & $2 \%$ & $0 \%$ \\
\hline Panama & 0 & 0 & 0 & 16 & $0 \%$ & $0 \%$ \\
\hline Peru & 2 & 0 & 0 & 25 & $8 \%$ & $0 \%$ \\
\hline Philippines & 3 & 2 & 0 & 16 & $19 \%$ & $0 \%$ \\
\hline Portugal & 0 & 0 & 0 & 19 & $0 \%$ & $0 \%$ \\
\hline South Africa & 5 & 3 & 1 & 86 & $6 \%$ & $1 \%$ \\
\hline Spain & 3 & 3 & 2 & 69 & $4 \%$ & $3 \%$ \\
\hline Taiwan & 4 & 2 & 2 & 80 & $5 \%$ & $3 \%$ \\
\hline Thailand & 0 & 0 & 0 & 4 & $0 \%$ & $0 \%$ \\
\hline Turkey & 0 & 0 & 0 & 10 & $0 \%$ & $0 \%$ \\
\hline Venezuela & 1 & 1 & 0 & 9 & $11 \%$ & $0 \%$ \\
\hline Total Weak RoL Sample & 123 & 81 & 35 & 2950 & $4.2 \%$ & $1.2 \%$ \\
\hline Total Weak RoL U.S. Matched Sample & 212 & 160 & 118 & 2826 & $7.5 \%$ & $4.2 \%$ \\
\hline Total Weak RoL \& U.S. Matched & 335 & 241 & 153 & 5776 & $5.8 \%$ & $2.6 \%$ \\
\hline
\end{tabular}

This table shows the number of firm-year observations and the number of restatements by each home country. Weak countries are those whose rule of law index score is below the country sample median (=1.64), while strong countries are those with an index score at or above the country median. Restatements reflect a single announcement rather than all the years restated. This is done by including only the last year of the restatement period before the announcement and dropping all prior years related to the same restatement. Restatements related to core accounts involve revenue recognition, cost of goods sold, operating expenses, or depreciation (Palmrose et al. 2004). We follow Hennes et al. (2008) and define restatements due to accounting irregularities as those that are followed by an external or board investigation. The US matched sample is obtained by performing an exact match on year and industry and a propensity score match based on four firm characteristics - size, leverage, ROA, and book-to-market - for each firm-year. 
TABLE 1: SAMPLE DESCRIPTIVE, 2000 - 2010 (CONTINUED)

Panel B: Distribution of cross-listed firms and restatements by country of domicile, firms from strong rule of law countries

\begin{tabular}{|c|c|c|c|c|c|c|}
\hline $\begin{array}{l}\text { STRONG RULE OF LAW (RoL) } \\
\text { COUNTRIES }\end{array}$ & $\begin{array}{c}\text { (1) } \\
\# \text { of restatements } \\
\text { - total } \\
\end{array}$ & $\begin{array}{l}\text { \# of restatements related } \\
\text { to core accounts }\end{array}$ & $\begin{array}{l}\text { (3) } \\
\text { \# of restatements due to } \\
\text { accounting irregularities }\end{array}$ & $\begin{array}{c}\text { (4) } \\
\text { \# of cross-listed } \\
\text { firm-years }\end{array}$ & $\begin{array}{c}(5)=(1) /(4) \\
\% \text { of restating } \\
\text { firm-years }\end{array}$ & $\begin{array}{c}(6)=(3) /(4) \\
\% \text { of restating firm-years, } \\
\text { accounting irregularities }\end{array}$ \\
\hline Australia & 9 & 5 & 2 & 142 & $6 \%$ & $1 \%$ \\
\hline Austria & 0 & 0 & 0 & 7 & $0 \%$ & $0 \%$ \\
\hline Belgium & 1 & 1 & 0 & 17 & $6 \%$ & $0 \%$ \\
\hline Canada & 87 & 63 & 14 & 1706 & $5 \%$ & $1 \%$ \\
\hline Czech Rep. & 0 & 0 & 0 & 1 & $0 \%$ & $0 \%$ \\
\hline Denmark & 0 & 0 & 0 & 25 & $0 \%$ & $0 \%$ \\
\hline Finland & 3 & 3 & 0 & 36 & $8 \%$ & $0 \%$ \\
\hline Germany & 4 & 3 & 1 & 169 & $2 \%$ & $1 \%$ \\
\hline Hong Kong & 9 & 6 & 4 & 245 & $4 \%$ & $2 \%$ \\
\hline Hungary & 1 & 1 & 0 & 15 & $7 \%$ & $0 \%$ \\
\hline Iceland & 1 & 1 & 0 & 7 & $14 \%$ & $0 \%$ \\
\hline Ireland & 7 & 3 & 2 & 202 & $3 \%$ & $1 \%$ \\
\hline Offshore Centers & 29 & 21 & 14 & 471 & $6 \%$ & $3 \%$ \\
\hline Japan & 6 & 6 & 0 & 245 & $2 \%$ & $0 \%$ \\
\hline Kazahkstan & 2 & 2 & 0 & 2 & $100 \%$ & $0 \%$ \\
\hline Luxembourg & 5 & 2 & 2 & 74 & $7 \%$ & $3 \%$ \\
\hline Netherlands & 16 & 12 & 5 & 258 & $6 \%$ & $2 \%$ \\
\hline New Zealand & 2 & 2 & 0 & 18 & $11 \%$ & $0 \%$ \\
\hline Norway & 0 & 0 & 0 & 31 & $0 \%$ & $0 \%$ \\
\hline Poland & 0 & 0 & 0 & 2 & $0 \%$ & $0 \%$ \\
\hline Puerto Rico & 0 & 0 & 0 & 4 & $0 \%$ & $0 \%$ \\
\hline Russia & 3 & 3 & 0 & 41 & $7 \%$ & $0 \%$ \\
\hline Singapore & 3 & 1 & 1 & 54 & $6 \%$ & $2 \%$ \\
\hline Sweden & 1 & 1 & 0 & 61 & $2 \%$ & $0 \%$ \\
\hline Switzerland & 14 & 13 & 8 & 177 & $8 \%$ & $5 \%$ \\
\hline United Kingdom & 21 & 17 & 3 & 493 & $4 \%$ & $1 \%$ \\
\hline Total Strong RoL Sample & 224 & 166 & 56 & 4503 & $5.0 \%$ & $1.2 \%$ \\
\hline Total Strong RoL Matched U.S. Sample & 315 & 225 & 178 & 4383 & $7.2 \%$ & $4.1 \%$ \\
\hline Total Strong RoL \& U.S. Matched & 539 & 391 & 234 & 8886 & $6.1 \%$ & $2.6 \%$ \\
\hline $\begin{array}{l}\text { All Non-U.S. Firms } \\
\text { (Strong and Weak RoL) }\end{array}$ & 347 & 247 & 91 & 7453 & $4.7 \%$ & $1.2 \%$ \\
\hline All Matched U.S. Firms & 527 & 385 & 296 & 7209 & $7.3 \%$ & $4.1 \%$ \\
\hline
\end{tabular}

This table shows the number of firm-year observations and restatements by home country. Weak countries are those whose rule of law index score is below the country sample median (=1.64), while strong countries are those with an index score at or above the sample median. Offshore centers include the Bahamas, Bermuda, the Virgin Islands, the Netherlands Antilles, the Cayman Islands, the Marshall Islands, and Papua New Guinea. Since these countries are either British or Dutch territories or have a legal system that follows the British legal system, we classify them as strong countries. Restatements related to core accounts involve revenue recognition, cost of goods sold, operating expenses, or depreciation (Palmrose et al. 2004). Restatements due to accounting irregularities are those followed by an external or board investigation (Hennes et al., 2008). Restatements reflect a single announcement rather than all the years restated by including the last year of the restatement period before the announcement. The US matched sample is obtained by performing an exact match on year and industry and a propensity score match based on firm characteristics - size, leverage, ROA, and book-to-market - for each firm-year. 
TABLE 2: DESCRIPTIVE STATISTICS: CROSS-LISTED FIRMS AND MATCHED US FIRM SAMPLE, 2000 - 2010

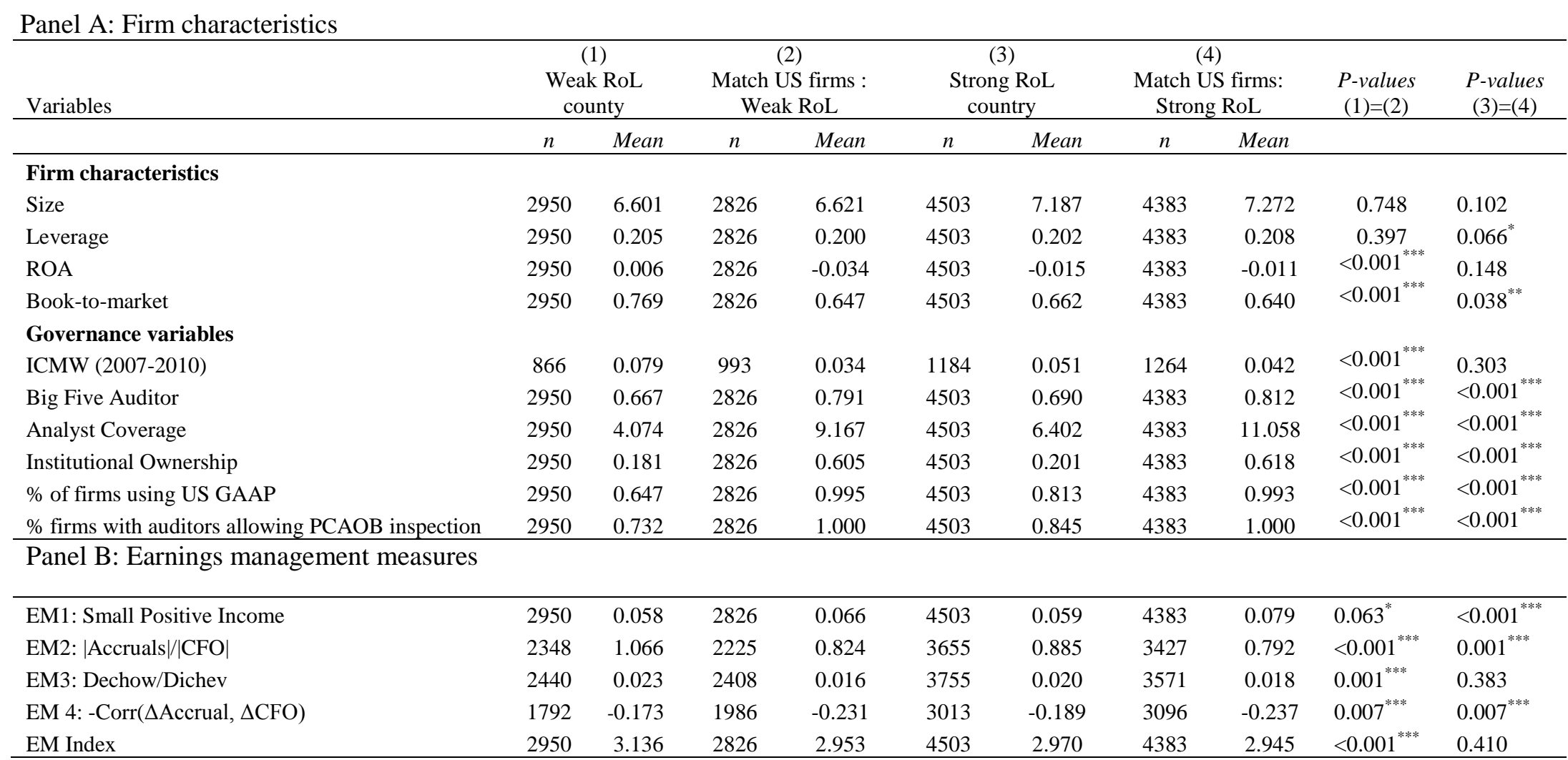

Notes: This table presents the firm-characteristics of the foreign cross-listed firms (by the level of home country rule of law) and their matched US firms. Column (1) shows the descriptive statistics for the sample of firms from weak rule of law countries and column (2) shows the equivalent for the matched sample of US firms. Column (3) shows the descriptive statistics for firms from strong (non-US) rule of law countries, and column (4) presents the equivalent for their US firm matched sample. The matched US sample is selected by performing a propensity score match on size, leverage, performance, and growth within the same two-digit SIC code and fiscal year. The number of observations for each variable is listed under " $n$ ". The $n$ for the ICMW variable is smaller because the ICMW variable starts from 2007 when auditor's assessment of internal controls became mandatory for US listed foreign firms. \% of firms using US GAAP is the percentage of firms that report using US GAAP or IFRS without reconciliation (as opposed to local GAAP with reconciliation to US GAAP). All other variables are defined in the appendix. $P$-values are based on t-tests for differences in mean. 
TABLE 3: RESTATEMENT CHARACTERISTICS OF CROSS-LISTED FIRMS AND MATCHED US FIRM SAMPLE, $2000-2010$

\begin{tabular}{|c|c|c|c|c|c|c|c|c|c|c|}
\hline & \multicolumn{2}{|c|}{$\begin{array}{c}(1) \\
\text { Weak RoL } \\
\text { Foreign firms } \\
\end{array}$} & \multicolumn{2}{|c|}{$\begin{array}{c}(2) \\
\text { Matched US firms } \\
\text { :Weak RoL } \\
\end{array}$} & \multicolumn{2}{|c|}{$\begin{array}{c}(3) \\
\text { Strong RoL } \\
\text { Foreign firms } \\
\end{array}$} & \multicolumn{2}{|c|}{$\begin{array}{c}(4) \\
\text { Matched US firms } \\
\text { : Strong RoL }\end{array}$} & \multirow[t]{2}{*}{$\begin{array}{c}\text { P-values } \\
(1)=(2)\end{array}$} & \multirow[t]{2}{*}{$\begin{array}{c}\text { P-values } \\
(3)=(4)\end{array}$} \\
\hline & $\mathrm{n}$ & Mean & $\mathrm{n}$ & Mean & $n$ & Mean & $n$ & Mean & & \\
\hline \multicolumn{11}{|l|}{ Restatement characteristics } \\
\hline Magnitude (\% of total assets) & 102 & -0.019 & 176 & -0.020 & 166 & -0.007 & 246 & -0.006 & 0.938 & 0.891 \\
\hline$\%$ Material restatements & 102 & 0.543 & 176 & 0.629 & 166 & 0.566 & 246 & 0.621 & 0.184 & 0.211 \\
\hline$\%$ using visible restatement disclosure & 123 & 0.618 & 212 & 0.854 & 224 & 0.585 & 315 & 0.800 & $<0.001^{* * *}$ & $<0.001^{* * *}$ \\
\hline Time to discovery & 123 & 10.10 & 212 & 6.22 & 224 & 9.14 & 315 & 5.99 & $<0.001^{* * *}$ & $<0.001^{* * *}$ \\
\hline Core account & 123 & 0.659 & 212 & 0.755 & 224 & 0.741 & 315 & 0.714 & $0.059^{*}$ & 0.493 \\
\hline \multicolumn{11}{|l|}{ Consequences } \\
\hline Litigation & 123 & 0.196 & 212 & 0.163 & 224 & 0.142 & 315 & 0.167 & 0.466 & 0.470 \\
\hline SEC Investigation & 123 & 0.089 & 212 & 0.061 & 224 & 0.085 & 315 & 0.124 & 0.338 & 0.151 \\
\hline CEO Turnover & 123 & 0.041 & 212 & 0.118 & 224 & 0.054 & 315 & 0.111 & $0.017^{* *}$ & $0.020^{* *}$ \\
\hline
\end{tabular}

Notes: This table presents the restatement characteristics of the foreign cross-listed firms (by the level of the home country rule of law index) and the matched US firms. We use the country sample median of the rule of law index $(=1.64)$ to classify firms as from strong or weak rule of law countries. The rule of law index is from the Worldwide Governance Indicators created by the World Bank (Kaufmann et al. (2003) and used in La Porta et al. (2006)). Column (1) shows the descriptive statistics for the sample of firms from weak rule of law countries and specification (2) shows the equivalent for the matched sample of US firms. Column (3) shows the descriptive statistics for the firms from strong rule of law countries, and column (4) presents the equivalent for their US firm matched sample. The matched US sample is selected by performing a propensity score match on size, leverage, performance, and growth within the same two-digit SIC code and fiscal year. The number of observations for each variable is listed under " $\mathrm{n}$ ". \% material restatments is the portion of restatements that are deemed material. We follow prior literature and define materiality using quantitative measures - those that have a greater than 5\% net income impact - and qualitative measures that capture the firms' intent. We measure intent based on restatements (i) where the error changes a loss into profit, (ii) that reverse an increase in earnings trend from prior years, (iii) are issued in periods of high financial distress, defined as firm-years in the highest leverage decile, or (iv) related to the core accounts. Core accounts are defined as revenue recognition, cost of goods sold, operating expenses, or depreciation. \% using visible restatement disclosure is the portion of restatements that are announced with a separate filing (e.g., form $8-\mathrm{K}$ or $6-\mathrm{K}$, a press release, or non-timely filings such as NT 10-K or equivalent). All other variables are defined in the appendix. See Table 1 for the list of countries with weak and strong rules of law. $P$-values are based on t-tests for differences in mean. 
TABLE 4: RESTATEMENT PROBABILITY OF FOREIGN FIRMS LISTED IN THE US 2007-2010 Restatement $_{\mathrm{i}, \mathrm{t}}=\beta_{0}+\beta_{1} \times$ Foreign firm $\left(\right.$ Weak RoL) indicator $_{\mathrm{i}, \mathrm{t}}+\beta_{2} \times \mathrm{ICMW}_{\mathrm{i}, \mathrm{t}, \text { before }}$

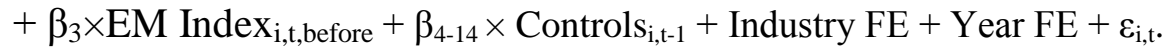

\begin{tabular}{|c|c|c|c|c|}
\hline \multirow[b]{2}{*}{ Variable (predicted sign) } & \multicolumn{2}{|c|}{ All restatements } & \multicolumn{2}{|c|}{ Irregularities only } \\
\hline & $\begin{array}{l}\text { (1) All foreign \& US } \\
\text { matched }\end{array}$ & (2) All foreign firms & $\begin{array}{l}\text { (3) All foreign \& US } \\
\text { matched }\end{array}$ & (4) All foreign firms \\
\hline Foreign firm indicator ( - ) & $\begin{array}{c}-0.637^{* * * *} \\
{[0.007]}\end{array}$ & & $\begin{array}{c}-1.026^{* * * *} \\
{[0.005]}\end{array}$ & \\
\hline Weak RoL indicator ( - ) & & $\begin{array}{l}-0.795^{*} \\
{[0.071]}\end{array}$ & & $\begin{array}{c}-1.646^{* *} \\
{[0.018]}\end{array}$ \\
\hline ICMW & $\begin{array}{l}1.881^{* * * *} \\
{[0.000]}\end{array}$ & $\begin{array}{l}1.161^{* * * * *} \\
{[0.003]}\end{array}$ & $\begin{array}{l}2.520^{* * *} \\
{[<0.001]}\end{array}$ & $\begin{array}{l}1.376^{* *} \\
{[0.015]}\end{array}$ \\
\hline EM Index & $\begin{array}{c}0.135^{*} \\
{[0.071]}\end{array}$ & $\begin{array}{c}0.064 \\
{[0.570]}\end{array}$ & $\begin{array}{c}0.117 \\
{[0.267]}\end{array}$ & $\begin{array}{c}-0.139 \\
{[0.346]}\end{array}$ \\
\hline Firm Controls & & & & \\
\hline Size & $\begin{array}{l}-0.153^{*} \\
{[0.053]}\end{array}$ & $\begin{array}{l}-0.110 \\
{[0.278]}\end{array}$ & $\begin{array}{c}-0.276^{* *} \\
{[0.030]}\end{array}$ & $\begin{array}{l}-0.225 \\
{[0.213]}\end{array}$ \\
\hline Leverage & $\begin{array}{c}0.430 \\
{[0.440]}\end{array}$ & $\begin{array}{c}0.396 \\
{[0.609]}\end{array}$ & $\begin{array}{c}0.431 \\
{[0.554]}\end{array}$ & $\begin{array}{l}-0.867 \\
{[0.530]}\end{array}$ \\
\hline ROA_current & $\begin{array}{l}-0.665 \\
{[0.393]}\end{array}$ & $\begin{array}{l}-0.364 \\
{[0.812]}\end{array}$ & $\begin{array}{l}-1.199 \\
{[0.213]}\end{array}$ & $\begin{array}{l}-1.179 \\
{[0.468]}\end{array}$ \\
\hline ROA_lagged & $\begin{array}{c}1.162 \\
{[0.243]}\end{array}$ & $\begin{array}{c}0.101 \\
{[0.955]}\end{array}$ & $\begin{array}{l}2.815^{*} \\
{[0.051]}\end{array}$ & $\begin{array}{c}1.694 \\
{[0.472]}\end{array}$ \\
\hline Book-to-Market & $\begin{array}{c}0.118 \\
{[0.496]}\end{array}$ & $\begin{array}{c}0.228 \\
{[0.402]}\end{array}$ & $\begin{array}{c}0.145 \\
{[0.534]}\end{array}$ & $\begin{array}{c}0.428 \\
{[0.323]}\end{array}$ \\
\hline Big five auditor & $\begin{array}{l}-0.263 \\
{[0.286]}\end{array}$ & $\begin{array}{c}-0.910^{* * *} \\
{[0.004]}\end{array}$ & $\begin{array}{l}-0.329 \\
{[0.362]}\end{array}$ & $\begin{array}{l}-1.019^{*} \\
{[0.076]}\end{array}$ \\
\hline Analyst coverage & $\begin{array}{l}-0.000 \\
{[0.977]}\end{array}$ & $\begin{array}{c}0.016 \\
{[0.511]}\end{array}$ & $\begin{array}{l}-0.000 \\
{[0.985]}\end{array}$ & $\begin{array}{l}-0.024 \\
{[0.557]}\end{array}$ \\
\hline Institutional ownership & $\begin{array}{l}-0.003 \\
{[0.991]}\end{array}$ & $\begin{array}{l}-0.248 \\
{[0.587]}\end{array}$ & $\begin{array}{c}0.216 \\
{[0.504]}\end{array}$ & $\begin{array}{l}-0.061 \\
{[0.919]}\end{array}$ \\
\hline Sales growth & $\begin{array}{l}-0.408 \\
{[0.175]}\end{array}$ & $\begin{array}{l}-0.012 \\
{[0.978]}\end{array}$ & $\begin{array}{l}-0.234 \\
{[0.544]}\end{array}$ & $\begin{array}{c}0.375 \\
{[0.560]}\end{array}$ \\
\hline Segments & $\begin{array}{l}-0.268 * \\
{[0.095]}\end{array}$ & $\begin{array}{c}0.064 \\
{[0.811]}\end{array}$ & $\begin{array}{c}-0.326 \\
{[0.177]}\end{array}$ & $\begin{array}{c}0.443 \\
{[0.304]}\end{array}$ \\
\hline Reporting standard & $\begin{array}{l}1.881^{* * * *} \\
{[<0.001]}\end{array}$ & $\begin{array}{c}1.330 \\
{[0.230]}\end{array}$ & & \\
\hline Country Controls & & & & \\
\hline Accounting difference & & $\begin{array}{c}0.333 \\
{[0.688]}\end{array}$ & & $\begin{array}{c}0.555 \\
{[0.709]}\end{array}$ \\
\hline Country market cap & & $\begin{array}{c}0.000 \\
{[0.795]}\end{array}$ & & $\begin{array}{c}-0.000 \\
{[0.256]}\end{array}$ \\
\hline Country GDP growth & & $\begin{array}{l}9.610^{*} \\
{[0.081]}\end{array}$ & & $\begin{array}{c}38.080^{* * * *} \\
{[0.000]}\end{array}$ \\
\hline Auditor liability & & $\begin{array}{c}0.702 \\
{[0.338]}\end{array}$ & & $\begin{array}{c}1.331 \\
{[0.316]}\end{array}$ \\
\hline Pseudo R-squared & 0.111 & 0.108 & 0.198 & 0.212 \\
\hline \# obs & 4,307 & 1,986 & 4,147 & 1,617 \\
\hline Year FE & YES & YES & YES & YES \\
\hline Industry FE & YES & YES & YES & YES \\
\hline
\end{tabular}

Notes: This table reports the estimation from a logistic regression of Models (1) and (2). In columns (1) and (2), the dependent variable Restatement $_{\mathrm{i}, \mathrm{t}}$ equals 1 if firm $i$ restated financial statements for year $t$, and zero otherwise. In columns (3) and (4), the dependent variable is an indicator variable that takes a value of 1 if firm reported a irregularities restatement for year $t$, and zero otherwise. We follow Hennes et al. (2008) and define restatements due to accounting irregularities as those that are followed by an external or board investigation. Foreign firm indicator is an indicator variable equal to 1 for non-US firms and zero otherwise. Weak RoL is an indicator variable equal to 1 for firms from countries with a weak rule of law and zero otherwise. We use the country sample median of the rule of law index $(=1.64)$ to classify firms as from strong or weak rule of law countries. The rule of law index is from the Worldwide Governance Indicators created by the World Bank (Kaufmann et al. (2003) and used in La Porta et al. (2006)). $I C M W_{i, t, p r i o r}$ is an indicator variable equal to 1 if the firm reported an ICMW for year t, prior to identifying the need to restate the financials, and zero otherwise. We use the original IC effectiveness report (rather than the amended reports) to focus exclusively on ICMW which precede the announcement of the restatement for year t. EM Index $x_{i, t \text { prior }}$ is the earnings management index variable constructed using the unrestated financials as described in Section III. Standard errors are clustered at the firm level. Significance is denoted by ***, **, and * for $1 \%$, 5\%, and $10 \%$ respectively, using a two-tailed test. 


\section{TABLE 5: HOME COUNTRY RULE OF LAW AND RESTATEMENT PROBABILITY, CONDITIONAL ON INTERNAL CONTROL MATERIAL WEAKNESSES (ICMW) 2007-2010}

Panel A: Likelihood of restatements conditional on ICMW, by home country rule of law

\begin{tabular}{|c|c|c|c|c|c|c|}
\hline & $\begin{array}{l}\text { All foreign } \\
\text { firms } \\
(\mathrm{N}=2,088)\end{array}$ & $\begin{array}{c}\text { US matched } \\
\text { firms } \\
(\mathrm{N}=2,320)\end{array}$ & $\begin{array}{l}\text { Foreign } \\
\text { Weak RoL } \\
(\mathrm{N}=876)\end{array}$ & $\begin{array}{l}\text { US matched } \\
: \text { Weak RoL } \\
(\mathrm{N}=1,025)\end{array}$ & $\begin{array}{c}\text { Foreign } \\
\text { : Strong RoL } \\
(\mathrm{N}=1,212)\end{array}$ & $\begin{array}{l}\text { US matched } \\
\text { : Strong RoL } \\
(\mathrm{N}=1,295)\end{array}$ \\
\hline ICMW & $10.94 \%$ & $32.18 \%$ & $7.35 \%$ & $23.53 \%$ & $15.00 \%$ & $37.74 \%$ \\
\hline No ICMW & $2.29 \%$ & $3.55 \%$ & $2.13 \%$ & $4.28 \%$ & $2.40 \%$ & $2.97 \%$ \\
\hline $\begin{array}{l}\text { Differences } \\
\text { [p-value] }\end{array}$ & $\begin{array}{c}8.65 \% \\
{[<0.001]}\end{array}$ & $\begin{array}{c}28.64 \% \\
{[<0.001]}\end{array}$ & $\begin{array}{c}5.22 \% \\
{[0.009]}\end{array}$ & $\begin{array}{c}19.25 \% \\
{[<0.001]}\end{array}$ & $\begin{array}{l}12.60 \% \\
{[<0.001]}\end{array}$ & $\begin{array}{c}34.76 \% \\
{[<0.001]}\end{array}$ \\
\hline
\end{tabular}

Panel B: Likelihood of restatements conditional on ICMW, by home country rule of law

Model: Restatement $\mathrm{i}_{\mathrm{i}, \mathrm{t}}=\beta_{0}+\beta_{1} \times \mathrm{ICMW}_{\mathrm{i}, \mathrm{t}, \mathrm{before}}+\beta_{2} \times \mathrm{EM}_{\text {Index }} \mathrm{i}, \mathrm{t}, \mathrm{before}+\beta_{3-14}$ Firm Controls $_{\mathrm{i}, \mathrm{t}-1}$ $+\beta_{15-17}$ Country Controls $\mathrm{c}_{\mathrm{c}, \mathrm{t}-1}+$ Industry FE + Year FE $+\varepsilon_{\mathrm{i}, \mathrm{t}}$. (3)

\begin{tabular}{|c|c|c|c|c|c|c|}
\hline & \multicolumn{2}{|c|}{ (1) } & \multicolumn{2}{|c|}{$(2)$} & \multicolumn{2}{|c|}{ (3) } \\
\hline Variable (predicted sign) & $\begin{array}{l}\text { All foreign } \\
\text { firms }\end{array}$ & $\begin{array}{l}\text { US matched } \\
\text { firms }\end{array}$ & $\begin{array}{c}\text { Foreign } \\
\text { firms } \\
\text { Weak RoL }\end{array}$ & $\begin{array}{l}\text { US matched } \\
\text { firms } \\
: \text { Weak RoL }\end{array}$ & $\begin{array}{l}\text { Foreign firms } \\
\text { : Strong RoL }\end{array}$ & $\begin{array}{l}\text { US matched } \\
\text { firms } \\
: \text { Strong RoL }\end{array}$ \\
\hline ICMW & $\begin{array}{l}1.191^{* * * *} \\
{[0.003]}\end{array}$ & $\begin{array}{l}2.507^{* * *} \\
{[<0.001]}\end{array}$ & $\begin{array}{c}0.587 \\
{[0.259]}\end{array}$ & $\begin{array}{l}2.083^{* * * *} \\
{[<0.001]}\end{array}$ & 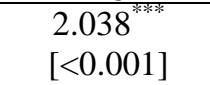 & $\begin{array}{l}3.160^{* * * *} \\
{[<0.001]}\end{array}$ \\
\hline $\begin{array}{c}\text { F-test: } \\
\text { F-stats }[p \text {-value }]\end{array}$ & \multicolumn{2}{|c|}{$6.59[0.010]^{* *}$} & \multicolumn{2}{|c|}{$4.10[0.043]^{* *}$} & \multicolumn{2}{|c|}{$3.01[0.083]^{*}$} \\
\hline EM Index & $\begin{array}{c}0.049 \\
{[0.668]}\end{array}$ & $\begin{array}{c}0.204^{*} \\
{[0.059]}\end{array}$ & $\begin{array}{l}-0.367^{*} \\
{[0.065]}\end{array}$ & $\begin{array}{l}0.261^{*} \\
{[0.061]}\end{array}$ & $\begin{array}{l}0.310^{* *} \\
{[0.034]}\end{array}$ & $\begin{array}{c}0.120 \\
{[0.438]}\end{array}$ \\
\hline Firm Controls & & & & & & \\
\hline Size & $\begin{array}{c}-0.079 \\
{[0.437]}\end{array}$ & $\begin{array}{l}-0.118 \\
{[0.373]}\end{array}$ & $\begin{array}{l}-0.486^{* *} \\
{[0.034]}\end{array}$ & $\begin{array}{l}-0.148 \\
{[0.402]}\end{array}$ & $\begin{array}{l}0.192^{*} \\
{[0.098]}\end{array}$ & $\begin{array}{l}-0.078 \\
{[0.694]}\end{array}$ \\
\hline Leverage & $\begin{array}{c}0.355 \\
{[0.647]}\end{array}$ & $\begin{array}{c}-0.029 \\
{[0.971]}\end{array}$ & $\begin{array}{c}0.908 \\
{[0.517]}\end{array}$ & $\begin{array}{c}0.074 \\
{[0.951]}\end{array}$ & $\begin{array}{c}0.094 \\
{[0.931]}\end{array}$ & $\begin{array}{c}0.165 \\
{[0.879]}\end{array}$ \\
\hline ROA_current & $\begin{array}{c}-0.280 \\
{[0.852]}\end{array}$ & $\begin{array}{c}-0.769 \\
{[0.418]}\end{array}$ & $\begin{array}{l}-0.795 \\
{[0.698]}\end{array}$ & $\begin{array}{c}0.648 \\
{[0.641]}\end{array}$ & $\begin{array}{l}-0.909 \\
{[0.613]}\end{array}$ & $\begin{array}{l}-1.565 \\
{[0.235]}\end{array}$ \\
\hline ROA_lagged & $\begin{array}{c}-0.111 \\
{[0.950]}\end{array}$ & $\begin{array}{l}2.069^{*} \\
{[0.086]}\end{array}$ & $\begin{array}{c}1.540 \\
{[0.632]}\end{array}$ & $\begin{array}{c}1.303 \\
{[0.438]}\end{array}$ & $\begin{array}{l}-2.121 \\
{[0.294]}\end{array}$ & $\begin{array}{l}3.347^{* * *} \\
{[0.040]}\end{array}$ \\
\hline Book-to-Market & $\begin{array}{c}0.203 \\
{[0.455]}\end{array}$ & $\begin{array}{c}0.029 \\
{[0.905]}\end{array}$ & $\begin{array}{c}0.135 \\
{[0.753]}\end{array}$ & $\begin{array}{l}-0.013 \\
{[0.972]}\end{array}$ & $\begin{array}{c}0.324 \\
{[0.384]}\end{array}$ & $\begin{array}{c}0.038 \\
{[0.899]}\end{array}$ \\
\hline Big five auditor & $\begin{array}{c}-0.931^{* * *} \\
{[0.004]}\end{array}$ & $\begin{array}{c}0.088 \\
{[0.798]}\end{array}$ & $\begin{array}{l}-1.424^{* * *} \\
{[0.021]}\end{array}$ & $\begin{array}{c}0.361 \\
{[0.458]}\end{array}$ & $\begin{array}{c}-0.392 \\
{[0.379]}\end{array}$ & $\begin{array}{c}-0.364 \\
{[0.451]}\end{array}$ \\
\hline Analyst coverage & $\begin{array}{c}0.020 \\
{[0.410]}\end{array}$ & $\begin{array}{c}-0.017 \\
{[0.466]}\end{array}$ & $\begin{array}{c}0.037 \\
{[0.461]}\end{array}$ & $\begin{array}{l}-0.013 \\
{[0.662]}\end{array}$ & $\begin{array}{l}-0.005 \\
{[0.857]}\end{array}$ & $\begin{array}{c}-0.021 \\
{[0.582]}\end{array}$ \\
\hline Institutional ownership & $\begin{array}{c}-0.264 \\
{[0.569]}\end{array}$ & $\begin{array}{c}0.054 \\
{[0.859]}\end{array}$ & $\begin{array}{l}-1.191 \\
{[0.130]}\end{array}$ & $\begin{array}{l}-0.109 \\
{[0.807]}\end{array}$ & $\begin{array}{c}0.006 \\
{[0.992]}\end{array}$ & $\begin{array}{c}0.269 \\
{[0.549]}\end{array}$ \\
\hline Sales growth & $\begin{array}{c}-0.058 \\
{[0.894]}\end{array}$ & $\begin{array}{l}-0.851^{*} \\
{[0.062]}\end{array}$ & $\begin{array}{c}0.073 \\
{[0.921]}\end{array}$ & $\begin{array}{l}-1.277 \\
{[0.107]}\end{array}$ & $\begin{array}{c}-0.441 \\
{[0.473]}\end{array}$ & $\begin{array}{c}-0.593 \\
{[0.290]}\end{array}$ \\
\hline Segments & $\begin{array}{c}0.048 \\
{[0.858]}\end{array}$ & $\begin{array}{c}-0.610^{* * * *} \\
{[0.003]}\end{array}$ & $\begin{array}{c}0.657 \\
{[0.160]}\end{array}$ & $\begin{array}{c}-1.010^{* * * *} \\
{[0.001]}\end{array}$ & $\begin{array}{c}-0.367 \\
{[0.177]}\end{array}$ & $\begin{array}{c}-0.352 \\
{[0.246]}\end{array}$ \\
\hline Reporting standard & $\begin{array}{c}1.557 \\
{[0.160]}\end{array}$ & $\begin{array}{c}-1.573 \\
{[0.150]}\end{array}$ & $\begin{array}{c}0.498 \\
{[0.663]}\end{array}$ & & & $\begin{array}{l}-1.755^{*} \\
{[0.079]}\end{array}$ \\
\hline
\end{tabular}




\section{TABLE 5: HOME COUNTRY RULE OF LAW AND RESTATEMENT PROBABILITY, CONDITIONAL ON INTERNAL CONTROL MATERIAL WEAKNESSES (ICMW) 2007-2010 (CONTINUED)}

\begin{tabular}{lcc|cc|cc}
\hline & \multicolumn{2}{c}{$(1)$} & \multicolumn{2}{c}{$(3)$} \\
& $\begin{array}{c}\text { All foreign } \\
\text { firms }\end{array}$ & $\begin{array}{c}\text { US matched } \\
\text { firms }\end{array}$ & $\begin{array}{c}\text { Foreign firms } \\
\text { : Weak RoL }\end{array}$ & $\begin{array}{c}\text { US matched } \\
\text { : Weak RoL }\end{array}$ & $\begin{array}{c}\text { Foreign firms } \\
\text { :Strong RoL }\end{array}$ & $\begin{array}{c}\text { US matched } \\
\text { : Strong RoL }\end{array}$ \\
\hline Country Controls & & & & & & \\
Accounting difference & -0.004 & & $2.849^{* *}$ & & -0.748 & \\
& {$[0.997]$} & & {$[0.044]$} & & $0.601]$ & \\
Country market cap & 0.000 & -0.000 & 0.000 & 0.000 & -0.000 & -0.000 \\
& {$[0.798]$} & {$[0.583]$} & {$[0.839]$} & {$[0.872]$} & {$[0.105]$} & {$[0.320]$} \\
Country GDP growth & 4.847 & -3.430 & 7.538 & -7.932 & -4.820 & -0.745 \\
& {$[0.314]$} & {$[0.576]$} & {$[0.455]$} & {$[0.319]$} & {$[0.642]$} & {$[0.938]$} \\
Auditor liability & 1.078 & & 0.679 & & 0.647 & \\
& {$[0.147]$} & & {$[0.715]$} & & {$[0.459]$} & \\
Pseudo R-squared & 0.103 & 0.158 & 0.215 & 0.153 & 0.152 & 0.222 \\
\# obs & 1,986 & 2,244 & 774 & 962 & 1,136 & 1,254 \\
Country controls & YES & YES & YES & YES & YES & YES \\
Year FE & YES & YES & YES & YES & YES & YES \\
Industry FE & YES & YES & YES & YES & YES & YES \\
\hline
\end{tabular}

Notes: Panel A shows the percentage of firm-years in each sample group that subsequently reports a restatement, split into firmyears with reported internal control deficiencies during the same year, prior to identifying the need to restate the financials. The sample period starts from 2007 when the auditor's assessment of internal controls became mandatory for US listed foreign firms. Panel B reports the estimation from a logistic regression. The dependent variable is an indicator variable that equals 1 if firm $i$ restated financial statements for year $t$, and zero otherwise. We use the country sample median of the rule of law index (=1.64) to classify firms as from strong or weak rule of law countries. The rule of law index is from the Worldwide Governance Indicators created by the World Bank (Kaufmann et al. (2003) and used in La Porta et al. (2006)). Coefficient estimates and p -values (in parentheses) are from seemingly unrelated regressions of restatement probability on ICMW and other controls. F-tests compare the coefficients of the ICMW variable for the weak rule of law country sample and their US matched sample (model (2)), as well as the strong rule of law country sample and its matched sample (model (3)). All other variables are defined in the appendix. Standard errors are clustered at the firm level. P-values are based on t-tests for differences in mean. Significance is denoted by $* * *, * *$, and $*$ for $1 \%, 5 \%$, and $10 \%$ respectively, using a two-tailed test. 


\section{TABLE 6: HOME COUNTRY RULE OF LAW AND RESTATEMENTS DUE TO ACCOUNTING IRREGULARITIES, 2000-2010}

$$
\begin{aligned}
& \text { Model: } \text { Restatement irregularities } \mathrm{i}_{\mathrm{i}, \mathrm{t}}=\beta_{0}+\beta_{1} \times \mathrm{EM}_{\text {Index }} \mathrm{i, \textrm {t } , \text { before }}+\beta_{2-13} \text { Firm Controls }_{\mathrm{i}, \mathrm{t}-1} \\
& +\beta_{14-16} \text { Country Controls }_{\mathrm{c}, \mathrm{t}-1}+\text { Industry FE }+ \text { Year FE }+\varepsilon_{\mathrm{i}, \mathrm{t} \cdot} \text { (4) }
\end{aligned}
$$

\begin{tabular}{|c|c|c|c|c|c|c|}
\hline & \multicolumn{2}{|c|}{ (1) } & \multicolumn{2}{|c|}{ (2) } & \multicolumn{2}{|c|}{ (2) } \\
\hline $\begin{array}{l}\text { Variable } \\
\text { (predicted sign) }\end{array}$ & $\begin{array}{c}\text { All } \\
\text { foreign } \\
\text { Firms }\end{array}$ & $\begin{array}{l}\text { US matched } \\
\text { firms }\end{array}$ & $\begin{array}{l}\text { Foreign firms } \\
\text { : Weak RoL }\end{array}$ & $\begin{array}{l}\text { US matched } \\
\text { : Weak RoL }\end{array}$ & $\begin{array}{l}\text { Foreign firms } \\
\text { : strong RoL }\end{array}$ & $\begin{array}{l}\text { US matched } \\
\text { : strong RoL }\end{array}$ \\
\hline EM Index & $\begin{array}{c}0.083 \\
{[0.326]}\end{array}$ & $\begin{array}{l}0.169^{* * *} \\
{[0.002]}\end{array}$ & $\begin{array}{l}-0.084 \\
{[0.532]}\end{array}$ & $\begin{array}{c}0.219^{* * *} \\
{[0.006]}\end{array}$ & $\begin{array}{c}0.206^{*} \\
{[0.058]}\end{array}$ & $\begin{array}{l}0.137^{* *} \\
{[0.044]}\end{array}$ \\
\hline $\begin{array}{c}\text { F-test: } \\
\text { F-stats }[p \text {-value }]\end{array}$ & 0.7 & {$[0.391]$} & 3.77[ & $052]^{*}$ & 0.29[ & 591] \\
\hline \# obs & 6511 & 6978 & 1929 & 2717 & 3511 & 4246 \\
\hline Pseudo R-squared & 0.106 & 0.095 & 0.237 & 0.136 & 0.092 & 0.089 \\
\hline Firm controls in Table 5 & & & YES & YES & YES & YES \\
\hline Country controls & YES & YES & YES & YES & YES & YES \\
\hline Year FE & YES & YES & YES & YES & YES & YES \\
\hline Industry FE & YES & YES & YES & YES & YES & YES \\
\hline
\end{tabular}

Panel A: Likelihood of restatement related to accounting irregularities (Hennes et al. 2008), conditional on EM

\begin{tabular}{|c|c|c|c|c|c|c|}
\hline & \multicolumn{2}{|c|}{$(1)$} & \multicolumn{2}{|c|}{$(2)$} & \multicolumn{2}{|c|}{$(2)$} \\
\hline $\begin{array}{l}\text { Variable } \\
\text { (predicted sign) }\end{array}$ & $\begin{array}{l}\text { All foreign } \\
\text { Firms }\end{array}$ & $\begin{array}{l}\text { US matched } \\
\text { firms }\end{array}$ & $\begin{array}{l}\text { Foreign firms } \\
\text { : weak RoL }\end{array}$ & $\begin{array}{l}\text { US matched } \\
\text { : weak RoL }\end{array}$ & $\begin{array}{l}\text { Foreign firms } \\
\text { : strong RoL }\end{array}$ & $\begin{array}{l}\text { US matched } \\
\text { : strong RoL }\end{array}$ \\
\hline EM Index & $\begin{array}{c}0.030 \\
{[0.576]}\end{array}$ & $\begin{array}{l}0.148^{* * *} \\
{[0.001]}\end{array}$ & $\begin{array}{c}-0.101 \\
{[0.284]}\end{array}$ & $\begin{array}{l}0.203^{* * *} \\
{[0.004]}\end{array}$ & $\begin{array}{c}0.098 \\
{[0.138]}\end{array}$ & $\begin{array}{c}0.105^{*} \\
{[0.058]}\end{array}$ \\
\hline $\begin{array}{c}\text { F-test: } \\
\text { F-stats }[p \text {-value }]\end{array}$ & \multicolumn{2}{|c|}{$2.70[0.100]^{*}$} & \multicolumn{2}{|c|}{$6.67[0.010]^{* * *}$} & \multicolumn{2}{|c|}{$0.01[0.933]$} \\
\hline \# obs & 7353 & 7067 & 2885 & 2736 & 4194 & 4293 \\
\hline Pseudo R-squared & 0.069 & 0.062 & 0.138 & 0.084 & 0.074 & 0.067 \\
\hline Firm controls in Table 5 & & & YES & YES & YES & YES \\
\hline Country controls & YES & YES & YES & YES & YES & YES \\
\hline Year FE & YES & YES & YES & YES & YES & YES \\
\hline Industry FE & YES & YES & YES & YES & YES & YES \\
\hline $\begin{array}{l}\text { Notes: This table reports th } \\
\text { variable that takes a value } \\
\text { restatements due to account } \\
\text { 2008). Panel B defines resta } \\
\text { accounts are defined as reve } \\
\text { rank for each firm for the ye } \\
\text { numbers to construct the un } \\
\text { values (in parentheses) are } f \\
\text { compare the coefficients of } \\
\text { well as the strong rule of la } \\
\text { are clustered at the firm lev } \\
5 \% \text { and } 10 \% \text { respectively }\end{array}$ & $\begin{array}{l}\text { emg irregularitie } \\
\text { ements due to } \\
\text { he recognition } \\
\text { ar across the } \mathrm{f} \\
\text { lerlying EM m } \\
\text { om seemingly } \\
\text { the aggregate } \\
\text { v country samp }\end{array}$ & $\begin{array}{l}\text { as those that } \\
\text { accounting irreg } \\
\text { cost of goods s } \\
\text { ur (or as many } \\
\text { easures. Higher } \\
\text { anrelated regres } \\
M \text { index variab } \\
\text { le and its match } \\
\text { based on t-tests }\end{array}$ & $\begin{array}{l}\text { larities as those } \\
\text { ld, operating ex } \\
\text { s are available) } \\
\text { alues indicate } \\
\text { ons of restatem } \\
\text { for the weak r } \\
d \text { sample. All ot } \\
\text { or differences in }\end{array}$ & $\begin{array}{l}\text { wed by an ex } \\
\text { it involved a c } \\
\text { ses, or deprec } \\
\text { asures of earn } \\
\text { er earnings m } \\
\text { probability on } \\
\text { of law countr } \\
\text { variables are }\end{array}$ & $\begin{array}{l}\text { account (Palmro } \\
\text { management. W } \\
\text { EMent. Coefficie } \\
\text { EMdex and o } \\
\text { ined in the Us apper }\end{array}$ & $\begin{array}{l}e_{i, t} \text { is an indic: } \\
\text { anel A, we def } \\
\text { ions (Hennes et } \\
\text { et al. 2004). C } \\
\text { average percen } \\
\text { use the unresta } \\
t \text { estimates and } \\
\text { er controls. F-t } \\
\text { natched sample } \\
\text { ix. Standard en } \\
* * \text {, and } * \text { for }\end{array}$ \\
\hline
\end{tabular}

Panel B: Likelihood of core account restatement (Palmrose et al. 2004), conditional on EM 


\section{TABLE 7: TIME-SERIES CHANGES IN HOME COUNTRY ENFORCEMENT AND RESTATEMENT LIKELIHOOD: MANDATORY ADOPTION OF IFRS 2000-2010}

\begin{tabular}{|c|c|c|}
\hline & (1) Foreign firms: Weak RoL & (2) Foreign firms: Strong RoL \\
\hline EM_Index & $\begin{array}{c}-0.159 \\
{[0.112]}\end{array}$ & $\begin{array}{c}0.064 \\
{[0.351]}\end{array}$ \\
\hline Post-IFRS & $\begin{array}{l}-1.300 \\
{[0.263]}\end{array}$ & $\begin{array}{l}-1.699^{* * *} \\
{[0.028]}\end{array}$ \\
\hline EM_Index * Post-IFRS & $\begin{array}{l}0.561^{* *} \\
{[0.040]}\end{array}$ & $\begin{array}{c}0.318 \\
{[0.102]}\end{array}$ \\
\hline $\begin{array}{c}\text { F- test: } E M \text { Index }+E M \text { In } \\
I F R S\end{array}$ & & \\
\hline $\begin{array}{l}\text { F-stats [p-value }] \\
\text { Firm Controls }\end{array}$ & $2.28[0.131]$ & $4.19[0.041]^{* *}$ \\
\hline Size & $\begin{array}{c}-0.099 \\
{[0.161]}\end{array}$ & $\begin{array}{c}-0.041 \\
{[0.521]}\end{array}$ \\
\hline Leverage & $\begin{array}{c}0.541 \\
{[0.445]}\end{array}$ & $\begin{array}{c}0.121 \\
{[0.835]}\end{array}$ \\
\hline ROA_current & $\begin{array}{l}-1.663 \\
{[0.207]}\end{array}$ & $\begin{array}{c}-2.048^{* * * *} \\
{[0.005]}\end{array}$ \\
\hline ROA_lagged & $\begin{array}{c}0.041 \\
{[0.975]}\end{array}$ & $\begin{array}{c}0.148 \\
{[0.861]}\end{array}$ \\
\hline Book-to-Market & $\begin{array}{c}0.183 \\
{[0.545]}\end{array}$ & $\begin{array}{c}0.146 \\
{[0.490]}\end{array}$ \\
\hline Big five auditor & $\begin{array}{c}-1.233^{* * *} \\
{[0.000]}\end{array}$ & $\begin{array}{c}0.460 \\
{[0.118]}\end{array}$ \\
\hline Analyst coverage & $\begin{array}{l}0.051^{* *} \\
{[0.039]}\end{array}$ & $\begin{array}{c}0.012 \\
{[0.438]}\end{array}$ \\
\hline Institutional ownership & $\begin{array}{l}-0.717 \\
{[0.205]}\end{array}$ & $\begin{array}{c}0.414 \\
{[0.205]}\end{array}$ \\
\hline Sales growth & $\begin{array}{c}0.266 \\
{[0.432]}\end{array}$ & $\begin{array}{l}-0.090 \\
{[0.749]}\end{array}$ \\
\hline Segments & $\begin{array}{c}-0.021 \\
{[0.932]}\end{array}$ & $\begin{array}{c}0.073 \\
{[0.725]}\end{array}$ \\
\hline Country Controls & & \\
\hline Accounting difference & $\begin{array}{c}0.958 \\
{[0.362]}\end{array}$ & $\begin{array}{l}1.331^{* *} \\
{[0.032]}\end{array}$ \\
\hline Country market cap & $\begin{array}{c}0.000 \\
{[0.254]}\end{array}$ & $\begin{array}{l}-0.000 \\
{[0.542]}\end{array}$ \\
\hline Country GDP growth & $\begin{array}{c}5.537 \\
{[0.323]}\end{array}$ & $\begin{array}{l}-2.550 \\
{[0.665]}\end{array}$ \\
\hline Auditor liability & $\begin{array}{c}0.703 \\
{[0.559]}\end{array}$ & $\begin{array}{c}0.160 \\
{[0.704]}\end{array}$ \\
\hline \# obs & 2885 & 4194 \\
\hline Pseudo R-squared & 0.145 & 0.079 \\
\hline Year FE & YES & YES \\
\hline Industry FE & YES & YES \\
\hline
\end{tabular}

This table reports the estimation from a logistic regression of equation (4) after including a dummy variable (Post IFRS) for the years after IFRS was adopted in the firm's home country and an interaction term (Post IFRS $\times$ EM index). We obtain from Daske et al. (2008) the list of countries and years that mandatorily adopt IFRS (Post IFRS). The dependent variable Restatement irregularities $_{i, t}$ is an indicator variable that takes a value of 1 if firm reported a irregularities restatement for year $t$, and zero otherwise. We define accounting irregularities as restatements that are subsequently followed by an internal or external investigation (Hennes et al. 2008). We use the country sample median of the rule of law index $(=1.64)$ to classify firms as from strong or weak rule of law countries. The rule of law index is from the Worldwide Governance Indicators created by the World Bank (Kaufmann et al. (2003) and used in La Porta et al. (2006)). Coefficient estimates and p-values (in parentheses) are from seemingly unrelated regressions of restatement probability on $E M$ and other controls. All other variables are defined in the appendix. Standard errors are clustered at the firm level. P-values are based on t-tests for differences in mean. Significance is denoted by $* * *, * *$, and $*$ for $1 \%, 5 \%$, and $10 \%$ respectively, using a two-tailed test. 


\section{TABLE 8: DISCLOSURE CHOICES AND HOME COUNTRY RULE OF LAW, CONDITIONAL ON REPORTING RESTATEMENTS 2000-2010}

Model: Visible restatement $\mathrm{i}_{\mathrm{i}, \mathrm{t}}=\beta_{0}+\beta_{1}$ Materiality $_{\mathrm{i}, \mathrm{t}}+\beta_{2-13}$ Firm Controls $_{\mathrm{i}, \mathrm{t}-1}$

$$
+\beta_{14-16} \text { Country Controls }{ }_{\mathrm{i}, \mathrm{t}-\mathrm{1}}+\varepsilon_{\mathrm{i}, \mathrm{t} \cdot}(5)
$$

\begin{tabular}{|c|c|c|c|c|}
\hline & \multicolumn{2}{|c|}{ (1) } & \multicolumn{2}{|c|}{ (2) } \\
\hline & $\begin{array}{l}\text { All foreign } \\
\text { Firms }\end{array}$ & $\begin{array}{l}\text { US Matched } \\
\text { Firms }\end{array}$ & $\begin{array}{c}\text { All } \\
\text { foreign }\end{array}$ & $\begin{array}{c}\text { US Matched } \\
\text { Firms }\end{array}$ \\
\hline \multirow[t]{3}{*}{ Materiality } & \multicolumn{2}{|c|}{$\begin{array}{l}\text { Quantitative } \\
(<5 \% \text { of } N I)\end{array}$} & \multicolumn{2}{|c|}{$\begin{array}{l}\text { Quantitative } \\
\text { \& qualitative }\end{array}$} \\
\hline & 0.221 & $1.590^{* *}$ & 0.189 & $1.691^{* * *}$ \\
\hline & [0.704] & {$[0.025]$} & [0.649] & {$[0.005]$} \\
\hline $\begin{array}{c}\text { F-test: } \\
\text { F-stats }[p \text {-value }]\end{array}$ & 2.23 & & 4.1 & $.041]^{* *}$ \\
\hline Firm Controls & & & & \\
\hline Size & $\begin{array}{c}0.091 \\
{[0.672]}\end{array}$ & $\begin{array}{l}-0.167 \\
{[0.453]}\end{array}$ & $\begin{array}{c}0.103 \\
{[0.626]}\end{array}$ & $\begin{array}{l}-0.010 \\
{[0.955]}\end{array}$ \\
\hline Leverage & $\begin{array}{c}0.402 \\
{[0.690]}\end{array}$ & $\begin{array}{l}4.380^{* *} \\
{[0.016]}\end{array}$ & & \\
\hline ROA_current & $\begin{array}{c}1.222 \\
{[0.421]}\end{array}$ & $\begin{array}{c}0.066 \\
{[0.983]}\end{array}$ & $\begin{array}{c}1.217 \\
{[0.397]}\end{array}$ & $\begin{array}{c}-0.388 \\
{[0.880]}\end{array}$ \\
\hline ROA_lagged & $\begin{array}{c}0.881 \\
{[0.488]}\end{array}$ & $\begin{array}{l}3.155 \\
{[0.450]}\end{array}$ & $\begin{array}{c}0.934 \\
{[0.451]}\end{array}$ & $\begin{array}{c}3.504 \\
{[0.305]}\end{array}$ \\
\hline Book-to-Market & $\begin{array}{l}-0.314 \\
{[0.492]}\end{array}$ & $\begin{array}{l}1.210^{*} \\
{[0.072]}\end{array}$ & $\begin{array}{l}-0.335 \\
{[0.456]}\end{array}$ & $\begin{array}{c}0.973 \\
{[0.141]}\end{array}$ \\
\hline Big five auditor & $\begin{array}{c}-0.784 \\
{[0.350]}\end{array}$ & $\begin{array}{l}-0.146 \\
{[0.847]}\end{array}$ & $\begin{array}{l}-0.818 \\
{[0.339]}\end{array}$ & $\begin{array}{l}-0.196 \\
{[0.796]}\end{array}$ \\
\hline Analyst coverage & $\begin{array}{c}0.002 \\
{[0.980]}\end{array}$ & $\begin{array}{l}-0.076 \\
{[0.275]}\end{array}$ & $\begin{array}{l}-0.000 \\
{[0.999]}\end{array}$ & $\begin{array}{l}-0.089 \\
{[0.163]}\end{array}$ \\
\hline Institutional ownership & $\begin{array}{c}0.083 \\
{[0.873]}\end{array}$ & $\begin{array}{l}-0.036 \\
{[0.967]}\end{array}$ & $\begin{array}{c}0.108 \\
{[0.837]}\end{array}$ & $\begin{array}{c}0.349 \\
{[0.687]}\end{array}$ \\
\hline Sales growth & $\begin{array}{c}-0.222 \\
{[0.632]}\end{array}$ & $\begin{array}{l}-0.625 \\
{[0.586]}\end{array}$ & $\begin{array}{l}-0.258 \\
{[0.585]}\end{array}$ & $\begin{array}{l}-0.646 \\
{[0.405]}\end{array}$ \\
\hline Segments & $\begin{array}{c}0.329 \\
{[0.480]}\end{array}$ & $\begin{array}{c}0.315 \\
{[0.643]}\end{array}$ & $\begin{array}{c}0.394 \\
{[0.374]}\end{array}$ & $\begin{array}{c}0.216 \\
{[0.709]}\end{array}$ \\
\hline Reporting standard & $\begin{array}{c}0.000 \\
{[0.864]}\end{array}$ & $\begin{array}{c}0.000 \\
{[0.272]}\end{array}$ & $\begin{array}{c}0.000 \\
{[0.780]}\end{array}$ & $\begin{array}{c}0.000 \\
{[0.418]}\end{array}$ \\
\hline Previous press releases & $\begin{array}{l}-25.207^{* * *} \\
{[0.021]}\end{array}$ & $\begin{array}{l}17.286 \\
{[0.426]}\end{array}$ & $\begin{array}{l}-26.437^{* *} \\
{[0.015}\end{array}$ & $\begin{array}{l}19.957 \\
{[0.378]}\end{array}$ \\
\hline Constant & $\begin{array}{l}-1.561 \\
{[0.330]}\end{array}$ & $\begin{array}{l}-4.923^{*} \\
{[0.056]}\end{array}$ & $\begin{array}{l}-1.621 \\
{[0.328]}\end{array}$ & $\begin{array}{l}-4.347^{*} \\
{[0.073]}\end{array}$ \\
\hline \# obs & 118 & 93 & 118 & 93 \\
\hline Pseudo R-squared & 0.181 & 0.286 & 0.184 & 0.228 \\
\hline Country controls in Table 4 & Yes & Yes & Yes & Yes \\
\hline Year FE & No & No & No & No \\
\hline Industry FE & No & No & No & No \\
\hline
\end{tabular}

Notes: This table presents a seemingly unrelated logistic regression of the likelihood of stealth restatements on restatement materiality. Visible restatement $t_{i, t}$ equals 1 if the restatement is reported with a separate filing (e.g., form 8-K, 6-K, or a press release) in addition to the regularly scheduled financial statements, and zero otherwise (Files et al. 2009). Material is an indicator variable that equals one if the restatement is considered a material restatement, and zero otherwise. Materiality is measured using quantitative measures in model (1), based on those that have greater than 5\% net income impact. In model (2), we consider qualitative measures and consider restatements to be material (i) where the error changes a loss into profit; (ii) where they reverse an increase in earnings trend from prior years; (iii) when they are issued by a firm in periods of high financial distress, measured as the firm-years in the highest leverage (liability divided by equity) decile; or (iv) when they are related to the core accounts. Standard errors are clustered at the firm level. Significance is denoted by ***, **, and * for $1 \%$, $5 \%$, and $10 \%$ respectively, using a two-tailed test. 